\title{
LA MEDIDA CAUTELAR EN LA ACCION DE AMPARO
}

\author{
Samuel B. Abad Yupanqui \\ "El problema del proceso es, ante todo, encontrar el hombre \\ digno de juzgar".
}

Carnelutti Francesco, Derecho y Proceso, Buenos Aires: E.J.E.A., p. 83.

Una de las razones, probablemente la decisiva, que ha determinado el frecuente empleo del amparo en el Perú, ha sido la posibilidad de poder contar rápidamente con una resolución cautelar que permita suspender provisionalmente el acto reclamado. Esta posibilidad de obtener una resolución con tales características, en base a lo dispuesto por el artículo 31 de la Ley de Habeas Corpus y Amparo, ha generado serios problemas en nuestra experiencia cotidiana, los cuales no se han limitado a enfrentar a las partes en litigio, sino que en ocasiones han afectado a terceros extraños al proceso e incluso propiciado serios conflictos sociales. Ello no ha sido causa exclusiva de una insuficiente regulación legislativa, sino que además se ha debido al empleo abusivo efectuado por ciertos abogados, y a la equivocada actuación de algunos magistrados quienes se han sentido armados de facultades que la Constitución jamás les reconoció.

$Y$ es que una institución tan delicada, bautizada por los mexicanos como suspensión del acto reclamado y conocida por los procesalistas como medida cautelar, no ha debido ser entendida al margen de los caracteres y presupuestos fundamentales que permitan su cabal otorgamiento, cuya observancia debe ser respetada por la judicatura en ejercicio de una especial madurez de criterio.

Es por ello que en el presente trabajo pretendemos a nalizar y 
reflexionar sobre los alcances de esta institución, la cual de operar correctamente permitiría --en palabras de Ricardo Couto (1)"mantener viva la materia de amparo" a fin de que el transcurso del tiempo no la haga desfallecer. Con tal objeto abordaremos previamente los orígenes de la institución en el derecho comparado, la importante influencia del derecho procesal en su configuración, $\mathrm{y}$ por último sus caracteres, presupuestos y funcionamiento en nuestra realidad, planteando los principales problemas que en ella se han generado.

Esperamos de esta manera aportar al análisis y debate de un instrumento que lejos de salvaguardar el valor eficacia en el proceso, ha servido con frecuencia para desnaturalizar su real contenido $\mathrm{y}$ alcances.

\section{LA SUSPE \SION DEL ACTO EN EL DERECHO COMPARADO}

El amparo de origen mexicano ha influido en el surgimiento y desarrollo de instrumentos similares en otros ordenamientos tanto de Latinoamérica como Europa, en los cuales ha adquirido determinadas peculiaridades que lo diferencian de la matriz original. Tales distinciones, que no enervan su principal identidad de tutelar derechos fundamentales, hacen necesario bosquejar brevemente los caracteres de la suspensión en el derecho comparado, a fin de poder contar con los elementos de juicio necesarios que nos permitan descubrir la influencia recibida por el artículo 31 de nuestra Ley de Habeas Corpus y Amparo. Con tal efecto conviene conocer la experiencia brindada tanto por México - cuna del juicio de amparo- como por Argentina - país donde ha tenido un singular desarrollo--.

\section{El caso mexicano}

El juicio de amparo mexicano se plasma por primera vez en la

(1) COUTO, Ricardo. Tratado teórico-práctico de la suspension en el amparo. 3ra. ed., Mexico; Porria, 1973, p. 40. 
Constitución del Estado de Yucatín de 1841 debido a la intervención de don Manuel Crescencio Rejón. Posteriormente don Mariano Otero, se encargaría de perfeccionarlo en el proyecto constitucional de minoría de 1842. siendo incorporado en al Acta de Reformas de 1847, e incluido en el tex to constitucional de 1857. En la actualidad, el amparo se encuentra regulado por la Constitución de 1917 y por su ley reglamentaria de 1936, vigentes con varias reformas.

Es en este contex to en que los mexicanos descubren la importancia de contar con un mecanismo previo a la sentencia definitiva que permita frenar, paralizar o detener el acto lesivo a fin de impedir su irreparable ejecución, la cual de suceder haría perder al amparo su finalidad (2).

Tal mecanismo, denominado suspensión del acto reclamado. tuvo como uno de sus primeros antecedentes al proyecto de ley elaborado por don José Urbano Fonseca durante la vigencia del Acta de Reformas de 1847 (3). Con posterioridad, fue incorporado en la Ley Orgánica de Amparo de 1861 y mantenido en las leyes sucesivas, alcanzando finalmente rango constitucional en el texto de 1917.

Un autor clásico como Ignacio Burgoa ha considerado que la suspensión en el amparo "es aquél proveído judicial (auto o resolución que concede la suspensión de plano u oficiosa, provisional o definitiva) creador de una situación de paralización o cesación. temporalmente limitada, de un acto reclamado de carácter positivo, consistente en imped ir para lo futuro el comienzo o iniciación, desarrollo o consecuencias de dicho acto, a partir de la mencionada paralización o cesación, sin que se invaliden los estados o hechos anteriores a éstas y que el propio acto hubiese provocado" (4). De acuerdo con tal concepto, la suspensión mexicana cuenta

(2) GONZALl:Z, Arturo l:l julcio de amparo, México: Porrúa, 1985, p. $209 . ;$

(3) BURGOA, Ignacio. El inicio de amparo, México: Porrúa, 1986, p. 706.

(4) BURGOA. Ignacio, obl cit., p. 711 ; 
con las siguientes características fundamentales:

a) Equivale a frenar, paralizar, detener o evitar la ejecución de un acto o el mantenimiento de una determinada situación (5). Carece asi de efectos restitutorios, los cuales son privativos de la sentencia definitiva (6). Por ello se afirma que la suspensión no opera frente a actos consumados, pues hacerlo implicaría restituir al quejoso en el goce de sus derechos afectados.

b) No anticipa provisionalmente los efectos de la sentencia definitiva. Hacerlo importaría efectuar una evaluación judicial previa de la posible inconstitucionalidad del acto lesivo, aspecto que resulta ex traño a la suspensión pues en ella no cabe examinar la validez constitucional del acto reclamado (7). Así lo ha entendido la Corte Suprema al sostener que cuando se resuelve un pedido de suspensión, no pueden estudiarse las cuestiones referidas al fondo del amparo (8).

c) Su viabilidad se determina de acuerdo con la naturaleza del acto reclamado. De modo tal que procede frente a actos de carácter positivo (aquellos que importan un hacer de la autoridad responsable), actos prohibitivos (los cuales imponen una obligación o limitación a la actividad de las personas), aquellos actos de tracto sucesivo pero sólo en lo referente a evitar la continuación de la lesión, y finalmente frente a las amenazas ciertas e inminentes. En cambio, no procede ante las omisiones (actos negativos) por no ser susceptible de suspender aquello que aun no se ha realizado, ni contra los actos consumados, es decir aquellos que se han realizado en toda su in tegridad $(9)$.

(5) Ibid. p. 712.;

(6) GONZALEZ, Arturo. ob. cit., p. 211.;

(7) BURGOA, Ignacio. ob. cit., p. 712.

(8) GONZALEZ, Arturo. ob. cit. p. 211 ;;

(9) BURGOA, Ignacio. ob. cit., p. 714. 
d) El procedimiento varía según se conceda en un proceso de amparo indirecto (bi instancial) o se trate de la suspensión otorgada de un amparo directo (uni instancial) (10). En el primer caso, cuyos alcances nos interesa destacar por ser más próximo a nuestra realidad, puede expedirse tanto de oficio -en situaciones expresamente señaladas $-o$ a pedido de parte -en los casos restantes-. En este último supuesto, ella puede ser provisional -concedida cuando la urgencia de la situación amerita una rápida actuación judicial sin audiencia a la otra parte-o definitiva - otorgada luego de una audiencia incidental y del contradictorio correspondiente-.

Las características anotadas no han sido aceptadas pacíficamente por la generalidad de la doctrina mexicana. Es así que autores como Ricardo Couto - a quien Mariano Azuela califica como "el teórico de la suspensión" (11) - postulan la necesidad de juzgar sumariamente la validez constitucional del acto reclamado, criticando aquella jurisprudencia que impide evaluar las cuestiones de fondo del amparo (12). Asimismo, considera que la suspensión debe producir los efectos de un "amparo provisional", en la medida que su otorgamiento anticipa los efectos de la sentencia de amparo de modo temporal y no definitivo por ser esto último propio de la resolución final, suspensión que también debería contar con efectos restitutorios. Desde otra perspectiva, de raíz procesal, Fix Zamudio critica las restricciones de la suspensión a la cual califica como una medida cautelar y a la que estima aplicable los lineamientos fijados por la doctrina procesal (13).

(10) Una clasificación muy difundida en el derecho mexicano distingue el amparo indirecto del amparo directo, debido al distinto tipo de procedimiento, a la diferente materia y a las instancias que originariamente lo conocen: Jueces de Distrito en el primer caso y Tribunales Colegiados de Circuito o la Corte Suprema en el segundo.

(11) AZUELA, Mariano. Juicio Critico. En: COUTO, Ricardo, ob. cit., p. 7.

(12) COUTO, Ricardo. ob. cit., p. 43 ;;

(13) FIX ZAMUDIO, Héctor. Reflexiones sobre la suspensión del acto reclamado en el juicio de amparo como providencia precautoria. En: La Justicia, México, 1976, No. 555, p. 59. 
En Argentina el amparo fue una creación jurisprudencial surgida a partir de los "leading cases" Angel Siri (1957) y Samuel Kot (1958). Posteriormente, luego de una importante experiencia jurisprudencial, fue reglamentado por la Ley 16986 de 18 de octubre de 1966, en actual vigencia.

La ley reglamentaria reconoce en su artículo $15^{\circ}$ de un modo indirecto la posibilidad de suspender el acto lesivo al disponer que "Sólo serín apelables la sentencia definitiva, las resoluciones previstas en el artículo $3^{\circ}$ y las que dispongan medidas de no innovar o la suspensión de los efectos del acto impugnado". De acuerdo con ello la doctrina y jurisprudencia argentina han entendido que:

a) La suspensión del acto impugnado es una medida cautelar de no innovar, en consecuencia deben serle de aplicación los presupuestos propios de toda medida cautelar. Por lo demás, así lo sostienen tanto José Luis Lazzarini (14), Germán Bidart (15), Nestor Sagués (16), Adolfo Rivas (17) y Eduardo de

(14) LAZZARINI, José Luis. Il juicio de amparo, Buenos Aires: La Ley, 1967. El referido tratadista considera que "la medida de no innovar encierra la suspensión del acto lesivo, e impide la continuación del agravio durante el corto lapso de sustanciación del proceso y en consecuencia no es retroactiva".

(15) Dicho autor entiende que "la suspensión encierra, en rigor, una orden de no innovar en forma de mandamiento de prohibición". BIDART CAMPOS, Germàn. Régimen legal y. Jurismrudencial del Amparo. Buenos Aires: Ediar, 1968, p. 328.

(16) SAgUES, Néstor Pedro. Derceho Procesat Constitucional-Accion de Amparo, 2a. ed., Buenos Aires: Astrea, 1988, Г. III, p. 462. En la citada obra se sostiene que "la suspensión de! acto impugnado consiste esencialmente en una orden de no innovar".

(17) Para quien resulta claro que "el Código Procesal Civil y Comercial de la Nación no contempla la suspensión como medida específica; de ahí que la doctrina considere que se trata en realidad de un supuesto comprendido en la prohibición de innovar, o si se quiere, en la medida de no innovar". RIVAS, Adolfo Armando. H:l amparo. Buenos Aires: Edic. La Rocia, 1987 , p. 350. 
Lázzari (18). Ello no significa que en el amparo argentino no quepan otra clase de medidas cautelares, v.g. de tipo innovativo, sino que ellas se decretan en virtud de la aplicación supletoria de las normas procesales civiles que implícitamente las contemplan a través de las llamadas medidas cautelares genéricas (Código Procesal Civil y Comercial de la Nación. Art. $232^{\circ}$ ).

b) Al ser una medida de no innovar no procede frente a hechos consumados, es decir aquellos integramente realizados; ni contra las omisiones. La suspensión, explica Bidart, se limita a detener el acto lesivo y conservar el "statu quo" existente, o evitar su inmediata ejecución si se trata de una amenaza. En consecuencia, jamás retrotrae la situación al estado de cosas anterior ni invalida los actos ya realizados.

c) El procedimiento para otorgar una medida cautelar no ha sido previsto por la ley 16986 , aplicíndose supletoriamente el Código Procesal Civil y Comercial de la Nación. La ley reglamentaria se limitó a reconocer indirectamente tales medidas, regulando el trámite de la apelación que se caracteriza principalmente por concederse en ambos efectos. aspecto que por lo demás ha sido severamente criticado por la generalidad de la doctrina platense.

II. LA INTLUENCIA DEL DERECHO PROCISAL EILA SUSPENSION DEL ACTO RECLAMADO

\section{Amparo Mexicano y Derecho Procesal}

Si bien los mexicanos fueron los creadores del amparo a mediados del siglo pasado, lo hicicron cuando la corriente cientifica del derecho procesal aún no se habia iniciado. En efecto, el amparo mexicano nació desprovisto de una teoría general del proceso

(18) DE LAZZARI, Eduardo Néstor. Medidas Cantelares. 2a. ed. La Plata: Libreria Editora Platense S.R.L., 1988, T. II. p. 264. Tambièn entiende que la suspensión del acto es una prohibición de innovar. 
que fortaleciera sus raices. Ello ha traido como consecuencia que por lo general los estudios efectuados sobre él no sólo hayan dejado de lado su importante vinculación con el derecho procesal, sino que incluso la hayan rechazado. En este sentido, Mariano Azuela - Magistrado de la Suprema Corte de México y Profesor de la UNAM - ha llegado a sostener que "es más lo que los procesalistas extranjeros tienen que aprender de nuestro juicio de amparo, para enriquecer sus doctrinas generales, que lo que nosotros podemos obtener de las últimas teorías en orden a esclarecer y sistematizar los principios de nuestra institución" (19).

Tal afirmación, cuyo sentido no compartimos, y que corresponde a una visión tradicional del amparo no ha sido aceptada por la totalidad de la doctrina. Es así que autores como Fix Zamudio - discípulo del notable procesalista español Niceto Alcalá-Zamora y Castillo-, han iniciado en México una corriente procesalista calificada por el propio Fix como minoritaria pero que cuenta con importantes seguidores. Ella, examina al amparo sin desconocer sus aspectos peculiares y además "tomando en consideración los lineamientos de la corriente científica del derecho procesal, que se inició en Alemania en la segunda mitad del siglo XIX y pasó posteriormente a Italia, país en el cual ha tenido un florecimiento ex traordinario, y actualmente también a España y Latinoamérica"' (20)..

Estas distintas maneras de examinar al amparo -una procesalista y la otra que deja de lado los lineamientos del derecho procesal- también coexisten al momento de estudiar la suspensión del acto.

$Y$ es que en el derecho mexicano se presenta una importante controversia respecto a reconocer la naturaleza cautelar de la suspensión y en torno a la posibilidad de aplicarle los lineamientos fijados por la doctrina procesal.

(19) AZUELA, Mariano. Ob. cit. p. 9.

(20) FIX ZAMUDIO, Héctor. El Juicio de Amparo y la enseñanza del Derecho Procesal. En: Boletin Mexicano de Derecho Comparado. México, 1975 , No. $22-23$, p. $428-429$. 
En efecto, Fix Zamudio distingue dos principales corrientes de opinión en torno a tan delicado asunto:

- Una, bajo la dirección de Ignacio Burgoa, compartida además por Mariano Azuela, Romeo León Orantes, Jorge Trueba Barrera, entre otros, considera que si bien "la suspensión en el amparo es una providencia o medida cautelar o precautoria, sin embargo no se le pueden aplicar los lineamientos de la doctrina del derecho procesal" (21).

- La otra corriente integrada por el propio Fix Zamudio y también por Humberto Briceño Sierra y J. Ramón Palacios, sostiene que la suspensión "constituye una especie dentro del género de las providencias precautorias o cautelares y a ella se le aplican los principios generales de esta institución establecidas por la doctrina procesal moderna" (22).

Nosotros, afiliándonos a la corriente procesalista defendida por Fix y recordando que el amparo es materia de estudio del Derecho Procesal Constitucional, pensamos que la suspensión del acto reclamado constituye en estricto una medida cautelar, razón por la cual resulta necesario acudir a la doctrina procesal que a ellas las informa.

\section{La medida cautelar en el Derecho Procesal Civil}

El Derecho Procesal a fin de salvaguardar el valor eficacia en el proceso, ha instituido las llamadas medidas cautelares que constituyen "una actividad preventiva que, enmarcada en una objetiva posibilidad de frustración, riesgo o estado de peligro, a partir de la base de un razonable orden de probabilidades acerca de la existencia del derecho que invoca el peticionante, según las circunstan-

(21) FIX ZAMUDIO, Héctor. Reflexiones sobre la suspensión del acto reclamado en el juicio de amparo como providencia precautoria. En: La Justicia, México, 1976, No. 555, p. 55.

(22) FIX ZAMUDIO, Héctor. ob. cit., p. 55. 
cias, y exigiendo el otorgamiento de garantias suficientes para el caso de que la petición no reciba finalmente auspicio, anticipa los efectos de la decisión de fondo ordenando la conservación o mantenimiento del estado de cosas existente o, a veces, la innovación del mismo según sea la naturaleza de los hechos sometidos a juzgamiento" (23).

Estas medidas cautelares, por su especial naturaleza, se caracterizan por:

- Sus efectos jurídicos permanecen hasta que se expida el fallo definitivo (provisoriedad): (24)

- Pueden ser modificadas antes de dictarse sentencia en la medida que la variación de las circunstancias así lo aconseje (variabilidad): (25).

- No constituyen un fin en sí mismas sino que están subordinados a la expedición de la resolución final, es decir operan como un instrumento para evitar el peligro que puede generar la demora en la expedición de la sentencia (instrumentalidad) (26).

Por otro lado, existen diversas clasificaciones de las medidas cautelares. De tal modo, un importante sector de la doctrina, distingue las medidas "no innovativas o conservativas" de aquellas "innovativas". Así, el procesalista argentino Jorge Peyrano entiende que:

(23) UL. LAL.A.ARI, lduardo, ob. cit., T. I. p. 6.

124) CALAMANDRII. Piero. Introduccion al estudio sistematico de las providencias cautelures. Buenos Aires: Ed. Bibliografia Argentina, 1945, pp. $36-37$.

(25) CALAMANDRL1, Piero, ob cit, p. 90.

(26) MONROY GLVHZ, Juan. Temás de proceso civil. Lima: Studium, $19 \times 7 . \mathrm{pP} \quad 37.38$ 
- Las medidas de no innovar buscan conservar o inmovilizar una situación de hecho para impedir los cambios que luego pudieran frustrar el resultado del proceso principal, careciendo de efectos retroactivos (27).

- Las medidas innovativas son excepcionales y tienden "a alterar el estado de hecho o de derecho existente antes de la petición de su dictado, (...), ordenando, sin que medie sentencia firme que alguien haga o deje de hacer algo en sentido contrario al representado por la situación existente". A diferencia de la anterior, esta sí cuenta con efectos retroactivos (27a).

En cambio, autores como Francesco Carnelutti (28), prefieren sustituir la anterior clasificación bipartita por una división tripartita que distinga tres aspectos marcadamente diferenciados: la inhibición, la eliminación y la anticipación del cambio. Para ello se refiere al:

Proceso cautelar inhibitorio, que se configura cuando el juez impide el cambio probable de una situación.

Proceso cautelar restitutorio, aquel en que el juez elimina el cambio ya ocurrido a una situación. disponiendo su restitución, $y$

(27) PHYRANO, Jorge. Medida cautelar mmolatra. Buenos Aires: De Palma, $1981, \mathrm{p}, 13$.

(27a) PEY RANO, Jorge. ob. cit., pp. 21-22.

(28) CARNELUTTI, Francesco. Derecho Procesal Civil yenal- Derecho y Proceso. Buenos Aires: AJEA, 1971. T.I.pp.415-416. In la citada obra. el notable procesalista italiano sostiene que "no resulta justo distinguir (. . .), el proceso conservativo del proceso innovativo, ante todo porque toda providencia aporta una novedad, esto es, algo que de otra manera no habría ocurrido: también cuando el jue $\iota$ opera en modo de impedir un cambio y de conservar asi las cosas tal como son, modifica el curso de la historia, según el cual de otro modo las cosas se habrian cambiado; por otra parte, también cuando innova disponiendo que sea eliminado un cambio ya ocurrido, conserva el estado de cosas existente precedentemente; por eso, conservación e innovación se implican reciprocamente". 
- Proceso cautelar anticipatorio, en el caso que el juez anticipe el cambio probable o posible de una situación.

En nuestra opinión, la clasificación tripartita propuesta por Carnelutti no resulta precisamente extraña a la división bipartita antes mencionada, pues el proceso cautelar inhibitorio se asemeja a la medida de no innovar, mientras que el restitutorio y el anticipatorio constituyen dos aspectos de la medida innovativa.

Adicionalmente, el Derecho Procesal ha fijado determinados presupuestos que permiten el despacho favorable de una medida cautelar. Conceptos como la apariencia del derecho invocado ("fumus bonis juris"), el peligro en la demora ("periculum in mora"), la contracautela y la irreparabilidad del perjuicio - este último tratándose de una medida innovativa-, constituyen presupuestos que el juez debe apreciar prudentemente para salvaguardar el valor eficacia en el proceso y evitar un uso indiscriminado y arbitrario que atente contra los nobles fines de esta institución.

\section{LA SUSPENSION DEL ACTO RECLAMADO EN EL AMPARO PERUANO \\ 1. Antecedentes}

La acción de amparo, como garantía autónoma, nace recién en la Constitución de 1979. Sin embargo, podemos hallarle antecedentes en la Ley No. 2223 de febrero de 1916 -en tanto permitía teóricamente la tutela de derechos distintos a la libertad individual (29)-, en el Habeas Corpus de la Constitución de 1933 -similar

(29) El artículo 7 de la Ley No. 2223 señalaba que "Todas las garantías contenidas en el Título IV de la Constitución del Estado, darán lugar a recursos destinados a amparar a los habitantes de la República que fueren amenazados en el goce de sus libertades o a hacer cesar las restricciones indebidas impuestas por cualquier autoridad. Son aplicables a estos recursos las disposiciones de la Ley de Habeas Corpus en cuanto a las autoridades que deban conocer de ellos, a las personas que puedan presentarlos y a las reglas de su tramitación". Este dispositivo ha sido considerado como el antecedente más remoto del artículo 69 de la 
por su amplitud al juicio de amparo mexicano (30)-, y en el Decreto Ley No. 17083 de octubre de 1968 que fijó un trámite especial -en la vía civil- para el Habeas Corpus (31). Empero, ninguna de tales normas concedió al juez la potestad de suspender provisionalmente el acto reclamado. Tan sólo un proyecto, que no llegó a

Constitución de 1933, vale decir del Habeas Corpus no sólo protector de la libertad individual sino de todos los demás derechos individuales y sociales. Por ello Ricardo Bustamante Cisneros, Presidente de la Corte Suprema de Justicia, diría que ". . . la Constitución de 1933, en su artículo 69, instituye esa acción en amparo de todos los derechos humanos y sociales declarados en ella, confiriendo categoría constitucional a la norma que ya regía en nuestro ordenamiento positivo, a tenor del artículo 7 de la Ley de 10 de febrero de 1916" (Habeas Corpus y Acción Popular. Trujillo: Publicaciones del Departamento de Extensión Cultural del Instituto Moderno, 1961, p. 8). Si bien es posible considerar al articulo mencionado como antecedente del Habeas Corpus de la Constitución de 1933, vale decir como un antecedente del amparo, en la práctica no tuvo mayor elaboración. Así, Domingo García Belaunde ha sostenido que "En cuanto a la jurisprudencia del Habeas Corpus en el período 1897-1933 es en extremo exigua limitándose a la defensa de la libertad personal" (til Habeas Corpus en el Perí, Lima: UNMSM, 1979, p. 30).

(30) El artículo 69 de la Carta de 1933 disponia que "Todos los derechos individuales y sociales reconocidos por la Constitución, dan lugar a la acción de Habeas Corpus". La amplitud de la norma explica la actitud del procesalista español Niceto Alcalá Zamora y Castillo, quien al comentar el anteproyecto del Código de Procedimientos Penales, prefirió utilizar el término "juicio de amparo" al de "recurso de Habeas Corpus" que como epígrafe encabezaba el título respectivo. (ALCALAZAMORA y CASTILLO, Niceto. La reforma procesal penal en el Pemi - El Anteprovecto Zavala, Revista del Foro, Lima, julio-diciembre 1939, Nos. 07 al 12, p. 376.

(31) Pese a que la Constitución de 1933 amplió el ámbito de protección del Habeas Corpus a todos los derechos individuales y sociales, el Código de Procedimientos Penales sólo lo reguló en función de la libertad individual. Con el objeto de establecer las pautas procesales para la tramitación del Habeas Corpus en el caso de los demás derechos individuales y sociales, se dictó el D.L. No. 17083, al que Fix Zamudio calificó como "Ley de A mparo" (FIX ZAMUDIO. Héctor. El derecho de amparo) en México ven lispaña. su influencia reciproca, en: Revista de fistudios Politiow. Madrid, No. 07, p. 229). 
convertirse en Ley, presentado a la Cámara de Diputados por el grupo parlamentario de la Democracia Cristiana en junio de 1967, propuso su introducción de acuerdo con los siguientes términos:

"Articulo 19.- Si el Juez, al examinar las circunstancias que rodean la restricción o violación de un derecho, hallare hechos susceptibles de probanza, ordenará la suspensión provisional de los actos reclamados, así como la del ejercicio del derecho, citando a audiencia pública para, dentro de las 72 horas siguientes a fin de que las partes of rezcan las pruebas o alegatos que convengan a su derecho. Cumplidos estos trámites el juez pronunciará resolución ordenando la cesación definitiva de los actos y procederá respecto de los responsables, con arreglo a los artículos 24, 25 y 26 de la presente ley" (32).

La doctrina nacional previa de la Ley No. 23506, tampoco ha brindando mayor atención a la problemática de la suspensión. Solamente autores como Domingo García Belaunde y Alberto Borea propusieron su implantación siguiendo la terminología mexicana (33).

A su turno la actual Constitución, como correspondía, tampoco abordó el tema de la suspensión dejando que la ley respectiva se avoque a su reglamentación.

(32) El proyecto fue publicado en el Boletin del Instituto de Ciencias Penales, Lima, UNMSM, No. 03, junio 1967, pp. 25-32. Nosotros citamos el tex to que obra como apéndice en: BERNAL MATALLANA, Gloria. El Habeas Corpus y sus reformas en el Perú, Tesis Bachiller PUC, 1969, p. 101. Cabe indicar que, según lo afirma Luis Taxa, el proyecto fue suscrito por el entonces diputado Valentín Paniagua (TAXA ROJAS, Luis. La proteccion jurisdiccional de los derechos constitucionales en el Perú, Tesis Bachiller PUC, 1968, p. 32).

(33) GARCIA BELAUNDE, Domingo; BOREA ODRIA, Alberto, Comentario al proyecto de Código de Procedimientos Penales en lo referente al Habeas Corpus. En: Revista del Foro, Lima, 1977, año LXIV, No. 1, p. 101. Cfr. también BOREA ODRIA, Alberto. La Defensa Constitucional: el amparo, Lima: Biblioteca Peruana de Derecho Constitucional, 1977, pp. 92-95. 
2. El artículo 31 de la Ley de Habeas Corpus y Amparo: el texto original (Le.' No. 23506)

Antes de examinar los alcances de la norma conviene recordar el texto original del artículo 31, incorporado en la Ley No. 23506, que se convirtió en la práctica en un instrumento que en manos de ciertos abogados y jueces negligentes sirvió para desvirtuar su naturaleza cautelar, convirtiendo al amparo en un verdadero "sanalotodo" al cual se acudía fundamentalmente para obtener una suspensión que satisfaga los intereses del quejoso. Esta penosa situación -que llegó a convertirse en un verdadero festín donde cada parte buscaba su propia suspensión ya sea en el juzgado de origen o en otro, y donde todo se suspendía, hasta por ejemplo proyectos de ley-, originó una reacción legislativa que dio a luz la reforma del artículo 31 por la Ley No. 25011. Las modificaciones sufridas por la norma original, y las razones que explican lo sucedido, ameritan el análisis del dispositivo vigente así como el de su predecesor ya derogado.

\subsection{Projectos y' Anteprovectos}

La Ley No. 23506 del 07 de diciembre de 1982 tuvo como antecedentes a los proyectos elaborados por Javier Valle-Riestra y Alberto Borea, de los cuales sólo el último abordó el tema de la suspensión. En efecto, el proyecto Borea disponía:

"Articulo 35. - E1 Juez o la Corte, al recibir la demandá instruirá al actor de la posibilidad de solicitar la suspensión del acto que reclama de inconstitucional".

"Articulo 36. - Mediante la suspensión del acto proveerá al levantamiento de toda medida destinada a atacar el derecho reclamado".

"Articulo 37. - Para decretar la suspensión del acto, el Juez deberá obligar a quien lo solicita a afianzar debidamente el derecho de la administración de llevar adelante el acto ejecutado. Esta fianza será acordada teniendo en cuenta el acto que se suspenda y la posibilidad económi- 
ca del agredido. En ningún caso se deberá denegar este beneficio por incapacidad económica del solicitante".

El citado proyecto utilizó el término suspensión del acto $-\mathrm{y}$ no la expresión medida cautelar - que como se ha indicado procede del derecho mexicano. Más aún al disponer que el solicitante debía prestar fianza suficiente, denotaba la influencia mexicana recibida, pues en dicho sistema en determinadas circunstancias se exige el cumplimiento de tal requisito para hacer efectiva la suspensión. Por lo demás el indicado tex to olvidó mencionar los requisitos indispensables para decretar la suspensión, así como los elementos que la caracterizan. La exposición que fundamentaba el proyecto tampoco precisó tales aspectos, limitándose a establecer:

"El artículo 35 obliga al Juez a informar que, de considerarlo conveniente, el reclamante puede pedir que se suspenda el acto mientras dura la tramitación a efectos de no hacer devenir en ilusorio el derecho del triunfante. Los artículos 36 y 37 regulan con mayor precisión y detalle este derecho".

La Comisión presidida por Domingo García Belaunde, que elaboró el anteproyecto de Ley de Habeas Corpus y Amparo, sustituyó los dispositivos del proyecto Borea por uno en el cual se decía:

"Articulo 32.- A solicitud de parte y en cualquier momento, el juez podrá disponer la suspensión del acto que dio lugar al reclamo, cuando por los fundamentos expuestos por el actor lo considere procedente".

La respectiva exposición de motivos se limitó a afirmar:

"Los artículos siguientes precisan los términos que debe observar el juez, a quien se faculta la suspensión del acto reclamado (artículo 39), facultad discrecional que se considera de suma importancia". 
En consecuencia, a juicio de la Comisión, la suspensión del acto reclamado - -expresión de origen mexicano- era una facultad discrecional del Juez concedida en base a lo fundamentado por el actor; sin embargo, se olvidó aclarar si en realidad se trataba de una medida cautelar a la que resultaran aplicables los lineamientos del derecho procesal.

El anteproyecto de ley fue aprobado por el Consejo de Ministros (18-12-81) y presentado al Congreso de la República como proyecto de ley del Poder Ejecutivo, siendo finalmente aprobado con algunas modificaciones y convirtiéndose en la Ley No. 23506.

\subsection{Alcances de la norma}

El artículo 31 de la Ley No. 23506 dispuso que "A solicitud de parte y en cualquier momento, el Juez podrá disponer la suspensión del acto que dio lugar al reclamo, cuando por los fundamentos expuestos por el actor lo considere procedente". De acuerdo con ello, la suspensión contaba con las siguientes características fundamentales:

- La norma se refería a la suspensión del acto reclamado, expresión de origen mexicano. En consecuencia resultaba coherente acudir a su antecedente mexicano que debía marcar sus lineamientos y caracteres.

- Procedía a pedido del actor, jamás de oficio y su concesión no estaba limitada a alguna etapa procesal sino que podía ser otorgada en cualquier momento, tanto en primera instancia, en la Corte Superior o en la Corte Suprema.

- Era facultad del Juez concederla en la medida que la fundamentación esgrimida por el actor así lo aconsejará.

- Se dictaba sin audiencia previa a la otra parte.

- Finalmente, no se precisaba si la resolución que la concedía era o no apelable. 
La suspensión del acto, que traducida al lenguaje procesal era una medida cautelar de no innovar, tuvo en la práctica cotidiana un intenso trajín en el que se apreció cómo la insuficiencia de la norma, aunada a un uso indiscriminado de la misma, así como a la equivocada actuación de algunos magistrados y a la carencia de una teoría coherente que le diera sustento, llevó a la crisis a la institución propiciando una reacción legislativa que buscó su inmediata modificación. Un interesante ejemplo de lo sucedido fue el empleo del amparo durante el pretendido proceso de estatización de las empresas bancarias, financieras y de seguros. En ello, tanto sectores de ideología neoliberal, como de centro izquierda, mostraron una singular similitud de opiniones.

En efecto, el parlamentario Felipe Osterling (PPC) en la $17^{\circ}$ sesión del Senado, realizada el 04 de octubre de 1988, sostuvo:

"Desde que se dictó la Ley de Amparo y sobre todo a raíz de la estatificación del sistema bancario y financiero, ha habido una enorme proliferación de acciones de amparo, y me parece que hay una tendencia dentro del Poder Judicial de abusar de la suspensión del acto respecto del cual se reclama.

Desde este punto de vista, quiero transmitirle a través de la Presidencia, al señor Valle-Riestra mi entero acuerdo en la posición que debe revisarse las facultades jurisdiccionales para suspender un acto que supuestamente infringe la Constitución mediante la Acción de Amparo" (34).

A su turno, Enrique Chirinos Soto (actualmente vinculado a las filas del FREDEMO), consideró:

"Todos estamos de acuerdo en que efectivamente, se ha

(34) Diario de los Debates del Senado. Primera Legislatura Ordinaria de $1988,17^{\circ}$ Sesión, 04-10-88, p. 176. 
abusado (. . .) de la Acción de Amparo, y que hay que ponerle freno a este abuso" (35).

Similar posición esgrimió Javier Valle-Riestra (APRA) (36) a quien le cupo una intensa participación en el debate parlamentario. Es por ello que resulta interesante analizar desde una perspectiva jurídica, lejos de las pasiones que en su momento generó, el funcionamiento de la medida cautelar durante la pretendida estatización del sistema financiero.

2.3. La aplicación del articulo 31 durante el proceso de estatización del sistema financiero

Con motivo del inicio del proceso de estatización de las empresas bancarias, financieras y de seguros, se suscitó en el pais uno de los más interesantes debates juridicos de nuestra historia republicana.

Los grandes grupos de poder afectados buscaron un instrumento que les permitiera mantener intangibles sus intereses, evitando la actuación gubernamental y desconociendo la aplicación de las disposiciones legales dictadas. Fue entonces como encontraron a un mecanismo procesal de nobles orígenes en el derecho comparado, pero de corta experiencia en nuestra realidad: la acción de amparo.

a) En efecto, desde un principio se presentaron varias demandas de amparo contra la decisión del gobierno de intervenir las empresas bancarias, financieras y de seguros en base a lo dispuesto por el D.S. No. 158-87-EF de 29 de julio de 1987, y de conformi-

(35) Diario de los Debates del Senado. Primera Legislatura Ordinaria de $1988,17^{\circ}$ Sesión, 04-10-88, p. 284.

(36) Diario de los Debates del Senado. Primera Legislatura Ordinaria de 1988, $17^{\circ}$ Sesión, 04-10-88, p. 274. 
dad con el artículo 132 de la Constitución (36a). Se trató de cuatro procesos de amparo.

De este modo, los accionistas de las empresas bancarias $\left(20^{\circ}\right.$ Juzgado Civil), financieras $\left(22^{\circ}\right.$ Juzgado Civil) y de seguros $\left(8^{\circ}\right.$ Juzgado Civil), plantearon sus respectivas demandas ante distintos juzgados, en las que de inmediato se dispuso la suspensión del acto lesivo. Solamente en un caso, iniciado por la accionista de una empresa financiera ante el $18^{\circ}$ Juzgado Civil, y en el cual se adujo cierta presión estatal, fue rechazado el pedido de suspensión. Ello motivó la solicitud del gobierno de acumular los procesos en trámite a fin de unificar criterios, lo cual no llegó a cumplirse pues la propia accionante se desistió de la demanda planteada. De estos procesos surgieron algunos aspectos sobre los que conviene reflexionar:

- En el amparo iniciado por Mario Brescia Caferata y otros accionistas de las Compañ ías de Seguros, el $8^{\circ}$ Juzgado Civil de Lima concedió la suspensión solicitada, que fue apelada por el Supremo Gobierno y elevada a conocimiento de la Segunda Sala Civil de la Corte Superior. La Sala por resolución de fecha 09 de setiembre de 1987 (Exp. No. 2026-87) declaró nulo el concesorio y en consecuencia improcedente el recurso de apelación presentado, pues entendió que no podía impugnarse la resolución que disponía la suspensión del acto reclamado. Con ello estableció un criterio que no fue uniforme a nivel de nuestros tribunales. Sucedió así algo paradójico pues algunas salas de la Corte admitían la apelación y otras las rechazaban. La

(36a) La intervención dispuesta por el Decreto Supremo 158-87-EF, implicaba la suspensión de la competencia de las juntas generales de accionistas de las empresas bancarias, financieras y de seguros. Las funciones y atribuciones que les correspondían a dichas juntas serían ejercidas por los llamados Comités de Administración, integrados por tres miembros nombrados por Resolución Suprema. Asimismo, el indicado decreto cesaba en sus funciones a los directorios de las empresas intervenidas, otorgando dichas funciones a los citados Comités de Administración. 
falta de un criterio unívoco importaba un serio atentado contra el principio de igualdad en la aplicación de la ley.

- En la acción de amparo iniciada por Betty Imaña Ramírez, accionista de Financiera Progreso S.A., el $18^{\circ}$ Juzgado Civil de Lima denegó el pedido de suspensión del acto reclamado, hecho que motivó la solicitud del gobierno de acumular los procesos en trámite. Ante tal situación, el juzgado corrió traslado a los demandantes en las restantes acciones de amparo presentadas a fin de evitar resoluciones contradictorias. Pocos dias después, la accionante Sra. Imaña se desistiría del amparo planteado. Sin embargo, quedó vigente la duda, ¿cabía la acumulación de procesos en los cuales existieran medidas cautelares contradictorias y cuya similitud era evidente?

b) Otro importante grupo de demandas planteadas fueron dirigidas contra la supuesta amenaza basada en el proyecto de ley de estatización de las empresas bancarias, financieras y de seguros que aún se estaba debatiendo en el Congreso de la República.

Se trató de catorce acciones de amparo interpuestas por diversos accionistas de las referidas empresas. Tres de ellas fueron presentadas ante el $22^{\circ}$ Juzgado Civil de Lima y las once restantes fueron planteadas ante el $24^{\circ}$ Juzgado Civil. En todas ellas, en forma sumamente rápida, fueron concedidas sendas medidas cautelares. Examinemos brevemente dos casos presentados ante distintos juzgados.

- En la acción de amparo planteada por Teófilo Huertas Vega $y$ otros accionistas de diversas empresas bancarias $\left(22^{\circ} \mathrm{Juzga}-\right.$ do Civil), con fecha 04 de setiembre de 1987 se dispuso la inmediata suspensión del acto reclamado pese a tratarse de una supuesta amenaza basada en un proyecto de ley.

Dicha resolución fue apelada por el Supremo Gobierno y elevada a la Tercera Sala Civil de la Corte Superior de Lima, la cual atribuyendo a la suspensión la calificación de medida cautelar y en consecuencia exigiendo el cumplimiento de los requisitos propios a toda medida de ese tipo (apariencia del 
derecho vulnerado e irreparabilidad del perjuicio) revocó con fecha 30 de setiembre de 1987 la suspensión indebidamente concedida.

Sin embargo, pese a la citada revocatoria, el juzgado el 13 de octubre del mismo año, debido a que el día anterior entró en vigencia la Ley No. 24723 de estatización del sistema financiero, dictó nuevamente una medida cautelar a favor de los accionistas de las empresas bancarias, que la Tercera Sala Civil de la Corte Superior en una resolución caracterizada por su escasa claridad recién dejó sin efecto el 9 de noviembre de 1988, es decir, luego de más de un año de haber sido dictada. Ello se debió no sólo a la clásica lentitud judicial, sino a las maniobras dilatorias que permitieron varios aplazamientos de los informes orales solicitados, así como a la recusación de los voçales que finalmente sería declarada infundada.

Este caso planteó serias interrogantes sobre los alcances de la medida cautelar, ¿resultaban viables frente a proyectos de ley? ¿Podían ser dictadas nuevamente pese a haber sido previamente revocadas? ¿Cabía ef ectuar informes orales y luego solicitar su aplazamien to en un incidente de medida cautelar? ¿El hecho que la Sala haya intervenido al momento de revocarla impediría que ella participe al conocer de la segunda apelación planteada? ¿Ello acaso importaba un prejuzgamiento que ameritaba la recusación de los vocales?

- En el amparo planteado ante el $24^{\circ}$ Juzgado Civil de Lima por Santiago Gerbolini Isola y otros accionistas de "El Sol" Compañía de Seguros Generales, se concedió inmediatamente la medida cautelar solicitada, que fue apelada en un sólo efecto y elevada a la Tercera Sala Civil de la Corte Superior de Lima. La Corte con fecha 23.10.87 revocó la suspensión otorgada y posteriormente el juzgado -con un nuevo titular pues el anterior magistrado había sido destituido- declaró improcedente la demanda planteada (10.11.87). Debido a ello el juez, sin percatarse que la resolución cautelar había sido revocada, dejó sin efecto la medida cautelar inicialmente concedida (10.11. 87). ¿Era posible dejar sin efecto una resolución anteriormente 
revocada? ¿Si el incidente de suspensión hubiera estado pendiente de resolver por la Corte Superior, el juez hubiera podido dejarla sin efecto? ¿Y si sólo se limitaba a declarar improcedente la demanda, ello significaba que automáticamente la medida cautelar quedaba sin efecto?

c) Un tercer número de acciones de amparo se dirigieron contra la Resolución CONASEV No. 148-87-EF/94.10 de 14 de agosto de 1987 que dispuso la suspensión de la negociación bursátil de las acciones representativas del capital social de las empresas bancarias, financieras y de seguros. Dicha resolución fue dictada en base a lo dispuesto por el Decreto Legislativo No. 198, Ley Orgánica de la CONASEV (Art. 11, Inc. a) y el Decreto Legislativo No. 211, Ley Normativa del Mercado Bursátil (Art. 15) (37). En esta ocasión, se trató de nueve demandas presentadas tanto en el $24^{\circ}$ Juzgado Civil (tres causas), como en el $22^{\circ}$ Juzgado Civil (seis procesos), y en todas ellas se concedieron sendas medidas cautelares que permitieron a los demandantes negociar sus acciones en la Bolsa de Valores. Como consecuencia de tal decisión se presentaron tres situaciones particulares:

- En cuatro procesos de amparo ( $22^{\circ}$ Juzgado Civil, Exp. Nos. 1641-87, 1766-87, 1767-87 y 1704-87) luego de concederse la medida cautelar solicitada y de poderse efectuar la respectiva transferencia de acciones, los accionantes se desistieron de su demanda, petición que rápidamente fue acogida por el juzgado. Con ello demostraron su poco interés en el proceso principal, pues lo único que se pretendía era obtener una medida cautelar para así poder vender libremente sus acciones. Acaso, ¿podía la suspensión ser utilizada para obtener lo que sería el resultado del proceso principal? ¿Qué interés tendría el de-

(37) La resolución dictada por la Comisión Nacional Supervisora de Empresas y Valores - CONASEV, conforme se desprendia de su parte considerativa, fundamentó la medida adoptada en el hecho que el debate en el Congreso del proyecto de ley de estatización de las empresas bancarias, financieras y de seguros estaba generando situaciones expectantes en el mercado que podían influir en el precio de las acciones, alterando el ritmo normal de la Bolsa de Valores. 
mandante en obtener sentencia si con la suspensión ya había conseguido el objeto de su pretensión? ¿En este supuesto se estaba manteniendo el "statu quo" o más bien se estaban anticipando los efectos del fallo definitivo?

- En dos casos, en los cuales el juez declaró improcedente la demanda luego de haber concedido la suspensión solicitada, los accionantes dejaron vencer los plazos establecidos para apelar de la sentencia que los "perjudicaba" (24 Juzgado Civil, Exp. Nos. 404-87 y 417-87). Evidenciaron así que lo único buscado era la obtención de la tan preciada medida cautelar, dejando en debate una seria interrogante, pues si la sentencia declaraba improcedente la demanda ieso significaba que automáticamente la medida cautelar quedaba sin efecto? Si ello era así y ya se habían vendido las acciones, ¿esa transferencia hubiera podido ser anulada en un juicio posterior?

Sólo en un caso cuando se rechazó la demanda por improcedente -que contaba con una medida cautelar inicialmente concedida-, los demandantes interpusieron recurso de apelación para salvaguardar así sus intereses $\left(24^{\circ}\right.$ Juzgado Civil, Exp. No. 406-87). En las dos causas restantes (220 Juzgado Civil, Exp. Nos. 1662-87 y 1784-87), los autos fueron apelados por el Supremo Gobierno pues la sentencia y la suspensión correspondiente favorecían a los demandantes.

d) Vinculadas a la transferencia de acciones del Banco de Crédito a sus trabajadores (37a) -que inicialmente fue calificada

(37a) La Ley No. 24723 dispuso la reserva para el Estado del sistema financiero, introduciendo diversas normas destinadas a fomentar el accionariado difundido, especialmente los artículos 13 y 14.

Dichas normas, de modo excepcional, exoneraban de la expropiación "a los actuales accionistas" de las empresas bancarias, financieras y de seguros, en la medida que observaran determinados requisitos, es decir, a nivel individual debería tratarse de personas naturales con acciones cuyo valor total no excediera de 40 UIT, y siempre que el conjunto de 
por el gobierno como una operación simulada - se plantearon ante el $9^{\circ}$ Juzgado Civil, dos acciones de amparo.

- Una de ellas, presentada por José Gagliardi Wakeham y otros accionistas y trabajadores del Banco de Crédito, que según la discutida operación de transferencia eran los nuevos propietarios, fue interpuesta cuando ya estaba en vigencia la Ley No. 24723, a fin de que el Supremo Gobierno se abstuviera de realizar actos que amenacen sus derechos de propiedad sobre las acciones del Banco y además contra el acuerdo de la CONASEV de fecha 21.10.87 que declaró en abandono la citada transferencia de acciones. El juzgado de inmediato dispuso la suspensión de "toda clase de actos que tiendan administrativamente a invalidar la operación bursátil (...) hasta que culmine este procedimiento" (Exp. No. 5024-87).

- La otra demanda fue planteada ante el mismo juzgado por Felipe Barclay P. y otros agentes de Bolsa (Exp. 5018-87). Como se sabe, la operación de transferencia de acciones fue declarada en abandono por la CONASEV debido a no haberse cumplido con efectuar el pago den tro del plazo establecido. Ello se debió a que los respectivos cheques no fueron abonados en la cuenta que la Bolsa de Valores tenía en el Banco de Comercio pues ellos no contaban con la firma del Comité de Administración del Banco de Crédito. Ante dicha situación, se concedió una medida cautelar disponiéndose que el Banco de Comercio "reciba y tramite la cobranza de dichos cheques", "que el Gerente

los accionistas exceptuados no excediera del $30 \%$ del capital social de las empresas sujetas a expropiación. Tales dispositivos motivaron que los propietarios del Banco de Crédito, interpretando opinablemente lo dispuesto por la ley, realizaran una operación de transferencia de acciones a sus trabajadores -que el gobierno inicialmente calificó como simulada - a fin de evadir la aplicación de la referida ley. Cabe recordar que la indicada transferencia fue declarada en abandono por el Director de la Rueda de Bolsa de la Bolsa de Valores aplicando el acuerdo adoptado por el Directorio de la CONASEV en virtud de la consulta efectuada por la Bolsa de Valores. Con posterioridad la criticada operación fue reconocida como válida por el propio gobierno mediante el Decreto Legislativo No. 468 . 
General de la Bolsa de Valores efectúe el depósito en cobranza de dichos documentos ante el Banco que corresponda", y que se suspenda la medida de "suspensión en el ejercicio de sus funciones dispuesta en contra de los accionantes por el Director de la Bolsa de Valores de Lima" (21.10.87).

Es decir, a través de una suspensión se quiso perfeccionar la operación celebrada en la Bolsa de Valores y que había sido declarada en abandono por la CONASEV. Se utilizó esta medida no para mantener las cosas tal como estaban, lo que hemos visto es el típico efecto de la suspensión mexicana inspiradora de nuestra institución, sino más bien para que los demandados realicen determinados actos que permitan la consumación de la indicada operación. Con ello, se dispuso algo que en México -tal como viene siendo entendida la suspensión- jamás hubiera podido suceder.

e) Otro grupo de acciones de amparo, estuvieron dirigidas a evitar la aplicación de la Ley No. 24723 y el inicio del procedimiento expropiatorio. Se trató de cuatro demandas presentadas ante distintos juzgados $\left(15^{\circ}, 16^{\circ}, 20^{\circ}\right.$ y $22^{\circ}$ Juzgado Civil de Lima).

Así por ejemplo, en el amparo planteado ante el $22^{\circ}$ Juzgado Civil (Exp. No. 1791-87) se ordenó "abstenerse de cometer actos en aplicación del artículo octavo de la Ley No. 24723 y de la R.S. No. 168-87-EF, que desvían a los demandantes del Juez y procedimiento previamente establecido para conocer y resolver de la expropiación de las acciones de los demandantes en el Banco Wiese Ltdo." El Juez de Primera Instancia dictó dicha resolución pese a que la Disposición Complementaria de la Ley No. 24723 disponía que en estos casos la autoridad competente para tramitar el amparo y conceder la suspensión era la Corte Superior (38). Más aún, si

(38) La referida disposición señalaba que "son de estricta aplicación los artículos 45 y 57 de la Ley General de Expropiación o Decreto Legislativo No. 313. Si pese a esto se intenta una acción de amparo contra lo dispuesto por esta ley o por Resoluciones Supremas dictadas en virtud de la misma, la acción se interpone por ante la Sala en lo Civil de turno 
como se sabe una acción judicial $-\mathrm{y}$ con mayor razón una medida cautelar- no puede obstruir, o paralizar un procedimiento de expropiación que por lo demás ya había sido iniciado ante la Corte respectiva.

f) Si bien durante el proceso de estatización los accionistas de las empresas bancarias, financieras y de seguros sobrecargaron de acciones de amparo al Poder Judicial (hemos detectado treintitrés) también el Estado, así como un particular muy asiduo a las acciones de garantía, tuvieron su cuota de participación.

- Es así que ante la Tercera Sala Civil de la Corte Superior de Lima, el Estado interpuso demanda de amparo contra el $24^{\circ}$ Juzgado Civil por su equivocada actuación judicial evidenciada al dictar una medida cautelar en la demanda de amparo planteada frente a un Proyecto de Ley. Es decir, se trataba de un amparo interpuesto contra la resolución cautelar dictada en otro proceso de amparo. En esta ocasión no fue concedida la medida cautelar solicitada, ¿acaso resultaba viable hacerlo?

- Un caso singular fue el de Santiago Sanguinetti Galindo quien planteó ante el $27^{\circ}$ Juzgado Civil de Lima demanda de amparo contra la Asociación de Bancos del Perú y otros a fin de que el Poder Judicial les ordenara el cumplimiento inmediato de la Ley No. 24723, de estatización del sistema financiero. Alegaba para ello su calidad de cuentacorrentista y ahorrista de diversos bancos lo cual le confería legítimo interés económico y moral. El Juez antes de decidir sobre la suspensión solicitada, "estan-

de la Corte Superior del lugar donde se afectó el derecho. Si la Sala admite la acción, designa al juez civil de turno para el trámite.

Una vez cumplimentado, la Sala señala día y hora para los informes orales si se hubiese pedido la palabra. Contra el fallo de la Sala las partes podrán interponer recurso de nulidad, dentro del plazo de tres días. Si se solicita la suspensión del acto reclamado, la Sala resuelve lo conveniente y su resolución es recurrible por ante la Segunda Sala en lo Civil de la Corte Suprema.

En todo lo no previsto en esta disposición, rige la Ley No. 23506". 
do al principio de contradicción que consagra nuestro ordenamiento procesal civil", dio traslado a la otra parte, para resolver luego de contestada la demanda. A su turno, el Juzgado no concedió la medida cautelar solicitada, pero dejó en pie la duda: ¿Podía darse traslado a la otra parte antes de resolver sobre un pedido de suspensión? ¿Sería ello conveniente y legal?

El pretendido proceso de estatización del sistema financiero que motivó encontradas oposiciones políticas, generó un intenso debate jurídico, cuyo curso hemos reseñado, y que demostró cuan insuficiente resultaba la norma contenida en el Art. 31 de la Ley No. 23506 y que necesaria era la presencia de una teoría general que le diera coherencia y sustento. Esta situación, aunada por cierto, a la presentada en los demás casos judiciales, donde por 1o general la motivación no estaba presente en las resoluciones de suspensión, donde siempre había la posibilidad de obtener una medida cautelar pues el demandante coordinaba previamente con el Juez y de acuerdo con ello presentaba su demanda o acudía a otro juzgado pues la práctica hizo que no se requiriera ir al de turno, y donde todo era susceptible de suspenderse, desde un convenio internacional hasta otra resolución cautelar, propició una reacción que facilitó la aprobación de la Ley No. 25011 de reformas a la ley de amparo.

3. El Artículo 31 de la Ley de Habeas Corpus y Amparo: el texto actual (Ley' No. 25011)

\subsection{Proyectos y Anteproyectos}

Los problemas generados por el mal funcionamiento de la Ley original, propiciaron el surgimiento de un afán reformador que se plasmó en la presentación y discusión de proyectos modificatorios del texto original del artículo 31 de la Ley.

De tal modo, en la 17a. Sesión del Senado de la República realizada el 04 de octubre de 1988 , se leyeron tanto el proyecto No. 1750/87-S suscrito por el Senador Enrique Bernales (15.04. 88), como el proyecto sustitutorio presentado por la Comisión 
de Justicia (31.05.88) elaborado sobre la base de un texto remitido por el Fiscal de la Nación con fecha 25 de noviembre de 1987.

El proyecto Bernales proponía la modificación del Art. 31 bajo los siguientes términos:

"A solicitud de parte y en cualquier momento, el Juez o la Corte podrá disponer la suspensión provisional del acto que dio lugar al reclamo, siempre que existan indicios razonables de que el bien materia de afectación pueda devenir en irreparable por la continuación del acto demandado como lesivo.

E1 Juez o la Corte corre traslado de esta petición por el término de un día, tramitando el pedido como incidente en cuerda separada $\mathrm{y}$, con la contestación expresa o ficta, resolverá lo conveniente. Contra la resolución del Juez o de la Corte, procede la apelación en ambos efectos o, en su caso, el recurso de nulidad, respecto del incidente. E1 Superior Tribunal o la Corte Suprema recepcionará el incidente en el término de un día, resolviendo lo conveniente, previa vista fiscal, en igual plazo, bajo responsabilidad" (39).

Esta propuesta, similar a la norma vigente, inicialmente no fue acogida pues se prefirió discutir el texto sustitutorio elaborado por la Comisión de Justicia, integrada entre otros por Javier Valle-Riestra e incluso suscrito por el propio Senador Bernales.

E1 texto sustitutorio, de mayor extensión, precisaba:

"En cualquier momento, la Corte Superior podrá disponer la suspensión del acto que dio lugar al reclamo, cuando su cumplimiento pudiere producir perjuicios

(39) Diario de los Debates del Senado. Primera Legislatura Ordinaria de $1988,17^{\circ}$ Sesión, 04.10 .88 , p. 271. 
irreparables; pero en estos casos, quien solicita la suspensión prestará fianza en monto prudencialmente determinado por el Juez, si éste considera que con la suspensión del acto perjudicare derechos de terceros.

La suspensión se solicitará al Juez de Primera Instancia que conozca de la demanda y se correrá traslado a la otra parte por el término de un día. El Juez podrá disponer, a su arbitrio, que en el término de 48 horas se constituya fianza bastante; y, en su caso, cumplida tal formalidad, formará cuaderno separado con copias certificadas de las piezas pertinentes y las elevará a la Corte Superior, la misma que resolverá, sin más trámite, en el término de 24 horas. La resolución que recaiga en el incidente podrá ser recurrida; pero si no lo fuera será elevada en consulta. En caso no se diera la fianza ordenada, se deja en suspenso la tramitación del incidente, hasta que se cancele aquella.

No procede la suspensión, en los siguientes casos:

1) Contra actos negativos;

2) Contra actos que protegen la salud pública;

3) Contra actos que promuevan la construcción de obras, constitución de servidumbres y demás relativas a la irrigación y a la viabilidad;

4) Contra actos derivados de la aplicación de una norma dictada por el Poder Ejecutivo que disponga la Expropiación, en el caso previsto en el artículo $3^{\circ}$ del Decreto Legislativo No. 313;

5) Contra los que dispongan la expulsión del territorio peruano de extranjeros indeseables, previa audiencia y derecho de interponer recurso de nulidad, conforme al artículo 13 del Pacto Internacional de Derechos Civiles y Políticos de las Naciones Unidas y al inciso 6) del artículo 22 del Pacto de San José de Costa Rica;

6) Contra los actos que tiendan a suprimir los juegos de azar; 
7) Contra actos derivados de la aplicación de una ley aprobada por el Congreso de la República o de un decreto legislativo;

8) Contra actos que velan por la moral pública:

9) Contra actos consumados e irreparables;

10) Contra actos administrativos dictados en interés social que afectan el orden público o que perjudique a un servicio público;

11) Contra actos legítimos encaminados a la investigación de un delito;

12) Contra actos relacionados con la defensa nacional;

13) En general, contra actos en cumplimiento de preceptos constitucionales" (40).

Durante el debate parlamentario, senadores de ideologías opuestas como Javier Valle-Riestra (APRA), Felipe Osterling (PPC), Enrique Chirinos (actualmente integrante del FREDEMO) y Róger Cáceres (FRENATRACA), entre otros, compartían un sentimiento común de modificar la regulación de la suspensión, para evitar los evidentes excesos que se habían presentado. Sin embargo, la discusión se centraba en torno a sus alcances, efectos y procedimiento. De esta manera, aspectos opinables como el otorgamiento de fianza suficiente para conceder la suspensión, su improcedencia frente a actos negativos y la complejidad del procedimiento establecido para su despacho, generaron intensa discusión al in terior de la Cámara. Ello motivó la variación del proyecto, que finalmente fue aprobado por el Senado en la sesión realizada el 10.11.88. El texto aprobado dispuso:

"Articulo 31. - A solicitud de parte y en cualquier etapa del proceso podrá disponerse la. suspensión del acto que dio origen al reclamo. De la solicitud corre traslado por el término de 48 horas. Con contestación o sin ella el

(40) Diario de los Debates del Senado. Primera Legisiatura Ordinaria de $1988,17^{\circ}$ Sesión, 04.10.88, p. 273. 
Juez o la Corte Superior, dentro del plazo de 48 horas, bajo responsabilidad, resolverá pudiendo disponer la suspensión del acto supuestamente lesivo y, según la naturaleza del caso, que se constituya o no fianza.

La resolución que dicte el juez o, en su caso, la Corte Superior, será recurrible en doble efecto ante la instaricia superior, la que resolverá en el plazo de 72 horas de elevados los autos, bajo responsabilidad.

En estos incidentes no interviene el fiscal, ni procede el recurso de nulidad. Consentida o ejecutoriada que sea la resolución que dispone la suspensión del acto, el juez o la Corte Superior sólo la aplicará cuando se constituya la fianza que se hubiere ordenado".

A su turno, la Cámara de Diputados remitió el proyecto aprobado en el Senado para que tanto la Comisión de Justicia y Derechos Humanos como la de Constitución, Leyes Orgánicas y Reglamento emitieran el dictamen correspondiente. Dichas Comisiones elaboraron un dictamen conjunto (18.11.88) en el que propusieron un tex to sustitutorio, pues se consideró que tanto el depósito de una fianza, como los términos fijados para su otorgamiento no eran convenientes para la eficacia de la suspensión, a la cual calificaban como medida cautelar de no innovar. Finalmente, el texto aprobado por la Cámara de Diputados, con las modificaciones introducidas en el curso del debate (24.11.88), dispuso:

"Articulo 31.- A solicitud de parte y en cualquier etapa del proceso, por cuenta, costo y riesgo del solicitante, podrá disponerse la suspensión del acto que dio origen al reclamo. De la solicitud se corre traslado por el término de un día, tramitando el pedido como incidente en cuerda separada, sin intervención del Ministerio Público. Con la contestación expresa o ficta el Juez o la Corte Superior resolverá dentro del plazo de dos días, bajo responsabilidad. La resolución que dicte el Juez o, en su caso, la Corte, será recurrible en doble efecto ante la instancia superior, la que resolverá en el plazo de tres días de elevados los autos, bajo responsabilidad". 
Devuelto el proyecto modificado a la Cámara de Senadores, la Comisión de Justicia y Derechos Humanos emitió dictamen (29.11.88) pronunciándose por la no insistencia "atendiendo a los perfeccionamientos que de nuestro proyecto ha efectuado la coladora".

Como quiera que el proyecto no logró ser aprobado en la Legislatura Ordinaria que terminaba el 15 de diciembre de 1988, el Presidente de la República convocó a legislatura extraordinaria para tratar entre otros aspectos las modificaciones a la Ley No. 23506. En dicha legislatura finalmente fue aprobada la ley No. 25011.

\subsection{Alcances de la Norma \\ a) ¿Suspensión del acto o medida cautelar?}

Durante el desarrollo del presente trabajo hemos destacado el origen mexicano de la suspensión y la intensa discusión existente sobre su contenido y alcances. Se ha mostrado también como en Argentina coexisten la suspensión - entendida como una medida cautelar de no innovar- y la llamada medida innovativa -regulada por las normas procesales civiles-.

Sin embargo, entre nosotros se plantea la duda, pues el artículo 31 de la Ley se refiere a. la "suspensión del acto" y no utiliza la expresión medida cautelar (41). ¿Acaso la suspensión es

(41) La versión actual del artículo 31, según la Ley No. 25011, dispone "A solicitud de parte y en cualquier etapa del proceso, por cuenta, costo y riesgo del solicitante podrá disponerse la suspensión del acto que dió origen al reclamo.

De la solicitud se corre traslado por el término de un día, tramitando el pedido como incidente en cuerda separada, sin intervención del Ministerio Público. Con la contestación expresa o ficta el Juez o la Corte Superior resolverá, dentro del plazo de dos días, bajo responsabilidad. La resolución que dicta el Juez o, en su caso, la Corte, será recurrible en doble efecto ante la instancia superior, la que resolverá en el plazo de tres días de elevados los autos, bajo responsabilidad". 
una medida cautelar? Y de responder afirmativamente, ¿qué clase de medida cautelar será? ¿De tipo innovativo o una medida de no innovar?

En primer lugar, si bien reconocemos que la expresión suspensión del acto surge en México desprovista de una connotación rigurosamente procesal, es evidente que por las características que incluso en México le han sido atribuidas (ser una resolución provisional dictada antes de la sentencia definitiva que busca evitar un perjuicio que haría perder al amparo su finalidad) constituye una verdadera medida cautelar. Ello, pues para calificar la naturaleza de las instituciones, no basta acudir al nombre con el que cuentan sino a sus caracteres fundamentales. En efecto, puede afirmarse que la suspensión del acto es una medida cautelar instaurada en el proceso de amparo, y como tal deben serle de aplicación los lineamientos propios del derecho procesal, en la medida que ellos sean compatibles con la naturaleza urgente y sumaria del remedio constitucional.

En segundo lugar, si seguimos la experiencia foránea que la informa y a la cual nos hemos referido con anterioridad, podremos concluir que ella constituye en rigor una medida cautelar de no innovar, y por ende debería limitarse a conservar e inmovilizar una situación de hecho o de derecho a fin de impedir los probables cambios que pudieran frustrar el resultado del proceso de amparo y la eficacia misma de la sentencia. En consecuencia, carecería de efectos retroactivos, y no procedería frente a omisiones (actos negativos), ni hechos consumados. Por lo demás, este carácter no innovativo fue reconocido en el dictamen conjunto de las Comisiones de Constitución, Leyes Orgánicas y Reglamento, y Justicia y Derechos Humanos de la Cámara de Diputados (18.11. 88) que inspiró la fórmula adoptada en la Cámara Baja y que posteriormente fue aprobada en el Senado. Incluso, uno de los comentaristas más destacados de la ley, integrante de la Comisión que elaboró el anteproyecto respectivo, así lo dejó entrever, al caracterizar a la suspensión como una medida provisional que debía recaer sobre actos positivos, y que era incapaz de hacer retroceder 
los hechos sucedidos hasta antes de haberse concedido (42).

Sin embargo, este carácter no innovativo, que respondía a los antecedentes que orientaron la introducción de la suspensión, no fue tomado mayormente en cuenta cuando los jueces empezaron a concederla. En ello, la experiencia brindada por el amparo durante el pretendido ensayo de estatización del sistema financiero, constituyó un claro ejemplo de cómo la suspensión no se limitó a mantener el "status quo", sino que avanzó mucho más convirtiéndose en la práctica en una verdadera medida innovativa. Pero realmente lo preocupante de este "avance jurisprudencial" - de una medida cautelar de no innovar a una de tipo innovativo-fue la escasa, por no decir nula, fundamentación que llevó a nuestros tribunales a considerar - sin decirlo pues se limitaban a concederlas- que el artículo 31 de la Ley, pese a la influencia mexicana recibida, también estaba reconociendo medidas innovativas:

- En efecto, en el amparo interpuesto por Juan Chico Quiróz contra el Alcalde del Concejo Provincial de Cajamarca, el Primer Juzgado Civil de esa ciudad dispuso la suspensión de la sanción interpuesta al accionante y en consecuencia ordenó se le restituyera en sus labores $(03.06 .86)$.

Con ello, sin mayor fundamentación, estaba restituyendo los derechos del afectado, y no sólo conservando la situación de hecho existente.

- A su vez, en los seguidos por Felipe Barclay P. y otros (Exp. No. 5018-87), el $9^{\circ}$ Juzgado Civil concedió medida cautelar

(42) BOREA ODRIA, Alberto. El Amparo y el Habeas Corpus en el Perú de hoy. Lima: Biblioteca Peruana de Derecho Constitucional, 1985, p. 225. En dicho texto el autor se pregunta "¿Qué es lo que puede suspender? Naturalmente que la suspensión debe de recaer sobre actos positivos o sobre la continuación de efectos positivos en el presente o posibles de verificarse en el futuro. La suspensión no puede retroceder en un minuto los hechos hasta antes de haberse decretado. Ni aún pudiendo el juez pronunciarse sobre esto deberá hacerse así pues no se trata de la sentencia definitiva". 
disponiendo que el Banco de Comercio "reciba y tramite la cobranza de dichos cheques", que el Gerente General de la Bolsa de Valores "efectúe el depósito en cobranza de dichos documentos ante el Banco que corresponda" y además que sea suspendida la medida de suspensión impuesta a los accionantes en el ejercicio de sus funciones (21.10.87). Es decir, por un lado está disponiendo que se realicen determinadas conductas, y por otro estaba restituyendo a los demandantes en el ejercicio de sus funciones.

- De modo similar, en el amparo presentado por el Sindicato de Trabajadores del Ministerio de Justicia contra los ministerios de Economía y Finanzas y otro, la Primera Sala Civil de la Corte Superior de Lima confirmó (30.01.90) el auto apelado y dispuso que tanto el Ministro de Economía y Finanzas como el de Justicia dieran cumplimiento a lo ordenado por el artículo 334 de la Ley No. 24977 (43). Es decir, dicha medida cautelar no se estaba limitando a petrificar una situación de hecho, sino que estaba ordenando la nivelación del Sector Justicia con el mejor remunerado de la Administración Pública.

En los casos mencionados -que tan sólo son unos ejemplos de lo que ha venido sucediendo en la realidad-pese a que el artículo 31 se refería a la expresión "suspensión" se concedieran verdaderas medidas cautelares de tipo innovativo. Ello, no nos preocuparía si no fuera porque la medida innovativa configura una institución muy peculiar, cuya presencia en el panorama procesal ha llevado a que autores como Jorge Peyrano la califiquen

(43) El citado artículo dispuso que "El sistema de homologación, cuya elaboración ha dispuesto el Supremo Gobierno, establecerá su aplicación progresiva comenzando por los Sectores de menores niveles remunerativos totales como Justicia y Trabajo, hasta que alcancen el nivel del Sector mejor remunerado incluyendo bonificaciones $\mathrm{y}$ demás beneficios sociales.

Lograda la nivelación de todos los sectores, cualquier incremento salarial o beneficio adicional se otorgará por igual a todos los sectores, sin excepción". 
como una medida excepcional, no sólo porque no resulta viable si existe otra providencia cautelar idónea para conseguir el fin perseguido - -v.g. una de no innovar--, sino porque además su otorgamiento exige una prudencia ex trema por parte de la judicatura (44), aspectos que por lo general no han sido debidamente valorados en nuestra jurisprudencia.

En síntesis, pensamos que la expresión "suspensión del acto" configura una medida cautelar de no innovar y por ende le es de aplicación la teoría procesal que informa a todas las medidas cautelares. Sin embargo, debemos reconocer, que nuestros jueces han extendido, -sin mayor fundamentación- los alcances de esta institución hasta darle también la posibilidad de incluir medidas de tipo innovativo. Ello en abstracto no nos parece incorrecto siempre que se tome en cuenta su naturaleza excepcional y se apliquen estrictamente los presupuestos exigidos para su despacho, aunque no podemos dejar de reconocer que a nuestro juicio tal interpretación excede los alcances del artículo $31^{\circ}$ de la Ley.

\section{b) Presupuestos para su otorgamiento}

En cuanto a los presupuestos que deben observarse para conceder una medida cautelar, el artículo $31^{\circ}$ de la Ley se limita escuetamente a señalar que "a solicitud de parte y en cualquier etapa del proceso, por cuenta, costo y riesgo del solicitante, podrá disponerse la suspensión del acto que dio origen al reclamo". Es decir, no brinda mayores elementos de juicio para determinar cuando debe concederse o rechazarse una solicitud de suspensión, dejando aparentemente al libre arbitrio del juez los casos en que ella debe ser otorgada. Probablemente, la versión original (Ley No. 23506) fue menos incompleta que el texto actual pues permitía su despacho "cuando por los fundamentos expuestos por el actor (el juez) los considere procedentes".

De tal manera, la falta de una regulación adecuada que exija

(44) PEYRANO Jorge. ob. cit. p. 29. 
el cumplimiento de determinados requisitos para suspender el acto reclamado, ha facilitado que nuestros magistrados otorguen medidas de esta naturaleza cuando ellos discrecionalmente lo decidan, olvidándose a menudo que la motivación de las resoluciones judiciales constituye "una garantía de la administración de justicia" que debe ser respetada.

Empero, si rescatamos la naturaleza cautelar de la suspensión y acudimos a la teoría procesal que la informa, llegaremos a la conclusión que su despacho está sujeto al cumplimiento de ciertos requisitos que el juez debe evaluar prudentemente y que son propios de toda medida cautelar. Veamos:

- Apariencia del derecho invocado ("fumus bonis juris"). En otras palabras, debe existir verosimilitud -sumariamente acreditada- de que el demandante está viendo amenazados o vulnerados sus derechos fundamentales. Como lo expresa Calamandrei, el Juez al evaluar este presupuesto debe limitarse a efectuar una cognición sumaria sobre la existencia del derecho; es decir, no se trata de una plena declaración de certeza sino tan sólo de una simple aproximación o hipótesis. "En sede cautelar basta que la existencia del derecho aparezca verosímil, (. . .), basta que, según un cálculo de probabilidades, se pueda prever que la providencia principal declarará el derecho en sentido favorable a aquel que solicita la medida cautelar" (45). Adicionalmente, creemos que este requisito exige implícitamente que la pretensión del demandante sea viable a través de la acción de amparo, vale decir que si ella es manifiestamente improcedente no será posible conceder una medida cautelar (46). Ello, en la medida que antes de evaluar suma-

(45) CALAMANDREI, Piero. ob. cit., p. 77.

(46) Así lo sostuvo el voto del doctor Gauna en la causa "Francisco Riccio" resuelta por la Corte Suprema Argentina el 26 de febrero de 1985.

Dicho magistrado sostuvo que "si la prohibición de innovar que se solicita (...), no es autónoma sino que se peticiona dentro del ámbito de la acción de amparo, para establecer su procedencia debe partirse del presupuesto -entre otros- que el derecho invocado fuere verosímil, exi- 
riamente la existencia del derecho afectado, debe examinarse si la demanda planteada es procedente, pues si ella no resulta viable sería innecesario efectuar un cálculo de probabilidades sobre la apariencia del derecho alegado. Así por ejemplo, de plantearse un amparo frente a un proyecto de ley, el pedido de medida cautelar efectuado debería ser rechazado pues mal se podría ingresar a evaluar la verosimilitud del derecho afectado si la propia demanda es evidentemente improcedente.

- Peligro en la demora ("Periculum in mora"). Es decir. no basta con que la medida cautelar busque prevenir un daño a los derechos del solicitante, sino que es necesario "que para obviar oportunamente el peligro de daño que amenaza el derecho, la tutela ordinaria se manifieste como demasiado lenta, de manera que (. . .), se deba proveer con carácter de urgencia a impedir con medidas provisorias que el daño temido se produzca o se agrave durante aquella espera" (47).

Este peligro en la demora, el cual debe ser evaluado prudentemente por el juez, permite el dictado de una medida urgente y rápida sin que resulte necesario esperar el fallo definitivo.

En este orden de ideas, pese a que por lo general las resoluciones de suspensión no se han caracterizado por ser fundamentadas, en algunos casos se han esgrimido argumentos interesantes. Así por ejemplo, en los seguidos por Teófilo Huertas Vega y otros con el Supremo Gobierno, la Tercera Sala Civil de la Corte Superior de Lima revocó (30.09.87) la medida cautelar concedida en el amparo iniciado contra la hipotética amenaza basada en un proyecto de ley, pues no se había acreditado la

gencia que no se cumple con la sola consideración a priori de que le pudiese asistir razón al peticionante, sino que es necesario además que esa razón pueda tener acogida por la vía de la acción impetrada, ya que si la acción intentada no es pertinente implícitamente hay carencia de jurisdicción para conocer en ella". Revista La Ley, Buenos Aires, Tomo 1985-C, p. 777.

(47) CALAMANDREI, Piero. ob. cit., p. 42. 
existencia del peligro en la demora "que no sólo se constituye por la existencia de un peligro, sino que también es indispensable que dicho peligro sea inminente (máxime si no aparecía) de los actuados una identificación concreta y definitiva con relación a la naturaleza de la amenaza que gravite sobre los actores". A su vez, en la demanda interpuesta por el Sindicato de Trabajadores del Ministerio de Justicia contra el Ministerio de Economía y Finanzas y otro, a fin de dar cumplimiento a lo dispuesto por el art. 334 de la Ley 24977 que disponía la nivelación progresiva del Sector Justicia con el sector mejor remunerado de la Administración Pública, la Primera Sala Civil de la Corte Superior de Lima (30.01.90) confirmó la medida otorgada sosteniendo que el pedido de suspensión debía evidenciar la apariencia del derecho invocado y el peligro en la demora el cual "está determinado por la constatación de parte del Juez de la urgencia de la medida cautelar para garantizar el cumplimiento del fallo definitivo", agregando que "si el órgano jurisdiccional no actúa ya, es muy probable que nunca pueda ser eficaz (pues de lo contrario) esta medida, se transformaría en un daño efectivo en razón del grave proceso inflacionario que sufre el país".

Irreparabilidad del perjuicio. - Al decir de Peyrano (48) se trata de un requisito especial exigido cuando se solicita el otorgamiento de una medida innovativa. Como se recordará, la teoría procesal ha distinguido entre aquellas medidas cautelares de no innovar y aquellas de tipo innovativo, cuya diferencia fundamental radica en la modificación o el cambio en la situación de hecho o de derecho producida por su dictado. En efecto, esta última cuenta con una naturaleza excepcional pues no sólo implica la imposibilidad de acudir a una medida de no innovar por su falta de idoneidad en el caso concreto, sino además porque su despacho exige una extrema prudencia por parte de la judicatura. Es por ello que para concederla no basta con la presencia de los requisitos antes mencionados,

(48) PEYRANO, Jorge, ob. cit., p. 27. 
sino que es consustancial a su dictado la posibilidad que de no hacerlo se produzca un "daño irreparable" al quejoso.

Ahora bien, el sintagma "daño irreparable", o en términos de José Acosta "agravio irreparable", genera algín margen de incertidumbre sobre sus reales alcances, pues se trata de la unión de dos términos que ofrecen cierta ambigüedad. Empero, siguiendo al citado autor, debe entenderse el elemento "agravio" como sinónimo de lesión $u$ ofensa, y la expresión "irreparable" como aquella "imposibilidad de revertir una situación jurídica al estado en que se hallaba antes del agravio" (49).

En otras palabras, sólo debe otorgarse una medida cautelar innovativa, cuando de no hacerlo el perjuicio generado por el acto lesivo traiga como consecuencia la imposibilidad que la sentencia definitiva cuando se dicte permita revertir la situación de hecho o de derecho al momento en que se hallaba antes de la lesión a los derechos del demandante. Así por ejemplo, Jorge Peyrano destaca como "leading case" el fallo "Bortulé, Néstor c/ Jockey Club de Rosario", pues en él la Corte concedió correctamente una medida innovativa (50). En dicho caso, el Jockey Club demandado había inhabilitado al jinete accionante impidiéndole el ejercicio de su labor por espacio de cuatro años, luego de seguirle un proceso en el cual no se le había permitido ejercitar su defensa (aspecto que evidenciaba la presencia de un primer requisito: la apariencia del derecho invocado). El Tribunal, percatándose que la sanción impuesta y la larga inactividad en el ejercicio de la profesión de jinete le generaría la pérdida de su aptitud profesional, concedió la medida cautelar solicitada pues de no hacerlo en el supuesto que la demanda fuese amparada ello no impediría el daño irreparable ya consumado. Así en este caso no resultaba suficiente dictar una medida de no innovar porque ella se hubiera limitado a mantener la situación de hecho dejando al agraviado sin poder ejercitar su profesión. Resultaba indispensable alterar la situación existente,

(49) ACOSTA, José V. Agravio Irreparable, Buenos Aires: Ediar, 1978. p. 76.

(50) PEYRANO, Jorge. ob. cit., pp. 56-57. 
levantando la inhabilitación impuesta al afectado y concediendo una medida cautelar innovativa.

En resumen, los presupuestos mencionados son aquellos que necesariamente deben estar presentes para la procedencia de una medida de suspensión. Sin duda, ellos no han sido claramente concebidos por el artículo 31 de la Ley de Habeas Corpus y Amparo, pero a tal exigencia se llega partiendo del reconocimiento de la naturaleza cautelar de la suspensión y en consecuencia de la aplicación de las categorías propias de la teoría procesal. Por lo demás, en algunas ocasiones nuestra jurisprudencia así lo ha dejado establecido. En efecto, en el incidente de suspensión No. 2191-89, la Primera Sala Civil de la Corte Superior de Lima, revocó con fecha 21 de diciembre de 1989 el auto apelado de dos de febrero del mismo año, declarando sin lugar la suspensión solicitada en atención a "que la medida cautelar no solamente debe concederse por cuenta, costo y riesgo del solicitante sino que fundamentalmente debe dictarse cuando por determinados elementos concurrentes a la vista del juez aparece un agravio de un derecho constitucional ("fumus bonis juris"), que de continuar por razones de la demora del proceso ("periculum in mora"), podría acarrear mayor perjuicio al demandante; por estas razones y estando a que de los presentes actuados no fluye la existencia de estos requisitos que la doctrina exige, REVOCARON el auto (apelado y) declararon sin lugar la medida cautelar solicitada por la demandante" (E1 Peruano, 21.03.90, p. 14).

\section{c) El problema de la contracautela}

Cuando el derecho procesal enumera los presupuestos que deben reunirse para el despacho de una medida cautelar incluye a la llamada contracautela. Ella, en realidad, no constituye un requisito fundamental para su procedencia sino más bien opera como un presupuesto de su ejecución, por cuanto luego de haber sido concedida no podrá ser ejecutada si es que el beneficiario no cumple con otorgar garantía suficiente que repare el posible perjuicio causad o al emplazado (51).

(51) DE LAZZARI, Eduardo Néstor. ob. cit., T. I, p. 40. 
La contracautela, entonces, consiste en la garantía (real, personal o caución juratoria), otorgada por el solicitante de la medida cautelar, que permite de ocasionarse un daño a la otra parte, indemnizarla si es que la demanda finalmente fuera rechazada. Como dejamos dicho, para la viabilidad de una medida cautelar es suficiente contar con la verosimilitud del derecho invocado, sin que resulte necesario la certeza absoluta del juzgador, aspecto que es propio de la sentencia definitiva. Ello, como se comprenderá, abre la posibilidad de una eventual concesión equivocada de la suspensión y el consecuente riesgo de un daño a la otra parte, resultando oportuno la exigencia de una contracautela que garantice la reparación del posible daño causado a la parte perjudicada.

La contracautela, por cierto, no es una institución exclusiva de la teoría procesal civil, pues incluso en determinadas circunstancias es exigida por la versión mexicana del amparo.

Así por ejemplo, si existiera la posibilidad de causar daños a un tercero (el llamado "tercero perjudicado"), se otorgará garantía suficiente para la ejecución de la medida de suspensión (art. 125, Ley de Amparo Mexicana), la cual podrá ser personal (fianza), real (prenda, hipoteca) o depósito en dinero. Incluso, se llega a admitir la facultad del tercero de otorgar una contra-garantía que pueda dejar sin efecto la suspensión dictada y en consecuencia permitir la ejecución del acto lesivo ( art. 126 Ley de Amparo). En cambio, tratándose de un amparo enderezado contra el cobro de tributos, la garantía exigida, por lo general, consiste en el depósito previo de la cantidad que se pretende cobrar (art. 135, Ley de Amparo). Asimismo, en el amparo argentino, por aplicación supletoria del Código Procesal Civil y Comercial de la Nación, se exige el otorgamiento de una contracautela para hacer efectiva la medida cautelar concedida, requisito que en la Provincia de Buenos Aires, según lo dispone el artículo 23 de la Ley No. 7166, es facultativo para el órgano jurisdiccional (52).

(52) El citado artículo dispone que "En cualquier estado de la instancia el juez o tribunal podrá ordenar, a petición de parte o de oficio, medidas de no innovar, las que se cumplimentarán en forma inmediata sin perjuicio de su ulterior notificación. 
Ahora bien, en nuestro país el problema se plantea cuando se discute la posibilidad de exigir la contracautela en el proceso de amparo. Sobre el particular existen algunas opiniones opuestas (53), incluso su tratamiento legislativo fue debatido tanto al momento de elaborar la versión original del artículo 31 como cuando se discutió el texto vigente, siendo en ambos casos rechazada.

El tema no deja de ser apasionante, pues sobre él existen razones suficientes para mantener una intensa discusión. Sin embargo consideramos -reconociendo lo opinable de nuestra afirmación-que tratándose específicamente del amparo, por la materia que busca tutelar, exigir una garantía real (prenda, hipoteca) o personal (fianza) para poder ejecutar la orden de suspensión limitaría la eficacia de la institución a aquellas personas que cuentan con los medios económicos suficientes, restringiendo su acceso a la generalidad de los justiciables. Empero ello no significa negar totalmente las ventajas de la contracautela, pues en algunos sistemas como el argentino existe regulada la llamada "caución juratoria" que creemos podría ser aplicada válidamente en nuestro país. Este tipo especial de contracautela prevista por el artículo 199 del Código Procesal Civil y Comercial de la Nación "consiste

En caso de hacerse lugar, el juez o tribunal podrá exigir la contracautela pertinente para responder de los daños que dichas medidas ocasionaren. La solicitud deberá resolverse en el mismo día de su presentación.

Cuando la suspensión acordada por la medida de no innovar afecte al servicio público o a la administración, podrá ser dejada sin efecto por el juez o tribunal, quien deberá declarar a cargo de la autoridad demandada o personalmente de los que la desempeñen la responsabilidad de los perjuicios que se deriven de la ejecución".

(53) Una posición a favor es esgrimida por MONROY GALVEZ, Juan, Cfr. T'mas de proceso Civil, Lima-Studium, 1987, pp. 33-34. También puede examinarse el trabajo del mismo autor titulado La medida cautelar en el proceso de amparo, en:Lecturas sobre Temas Constitucionales, Lima: CAJ, 1989, pp. 114-115. En cambio, una posición en contra de la exigencia de la contracautela (fianza) en el amparo ha sido sostenida por BOREA ODRIA, Alberto. El amparo y el Habeas Corpus en el Peri de hoy. Lima: Biblioteca Peruana de Derecho Constitucional, 1985, pp. 231-232. 
en la manifestación solemne de quien obtiene la medida, efectuada por escrito en el expediente, de que se hace cargo de los eventuales daños y perjuicios" (54). Es decir, trasladando la institución al caso peruano, podría exigirse que el beneficiado con una medida cautelar antes de su ejecución se comprometa en escrito con firma legalizada por el Secretario de Juzgado a responder por los posibles daños que genere la suspensión concedida si la demanda fuera finalmente rechazada. En tal supuesto, y dentro de un breve plazo contado desde la fecha en que queda consentida o ejecutoriada la sentencia, en un procedimiento distinto al amparo, y a pedido de parte, el juez deberá establecer el monto de la indemnización que el afectado por la suspensión deberá obtener, sin necesidad de ingresar a discutir la eventual culpabilidad del demandante, pues ella ya quedó establecida cuando aquel se comprometió formalmente a responder por los posibles daños causados.

La caución juratoria, que según la crítica del procesalista argentino Eduardo de Lazzari se ha convertido por obra de los Tribunales en "una especie de fondo común, al que se recurre como principio general, exigiendo otro tipo de contracautelas solamente como excepción" (55), podría operar como un elemento que evite la absoluta irresponsabilidad de la que gozan en los momentos actuales aquellos que se beneficiaron con medidas cautelares finalmente rechazadas.

d) Cuenta, costo y riesgo: el problema de la responsabilidad

La versión actual del artículo 31 dispone que podrá suspenderse el acto reclamado a solicitud de parte y "por cuenta, costo y riesgo del solicitante". Tal expresión, tomada de la normatividad propia del embargo preventivo ( art. 235, C.P.C.: "E1 embargo preventivo. . . se entiende decretado de cuenta y bajo la responsabilidad de quien lo solicita"), en modo alguno constituye una con-

(54) DE LAZZARI, Eduardo Néstor. ob. cit., T. I, p. 115.

(55) Ibid., p. 115. 
tracautela pues no garantiza el probable daño causado a la otra parte si es que finalmente la demanda fuera rechazada. Por lo demás, al carecer de un vehículo procesal expeditivo, se ha convertido en una interesante declaración lírica que no soluciona el grave problema ocasionado por el otorgamiento injustificado de medidas cautelares.

No obstante lo afirmado, procesalistas de la talla de Guiseppe Chiovenda han llegado a sostener que las medidas cautelares se ejecutan "por regla general, a cuenta y riesgo del actor, es decir, que éste, en caso de revocación o desistimiento, (es) responsable de los daños causados por la resolución, tenga o no culpa" (56). En otras palabras, se considera que la expresión "cuenta y riesgo", similar a la contenida en el artículo 31 de la Ley, obliga al beneficiado con la medida cautelar a indemnizar por los daños causados con independencia de su culpabilidad, vale decir asumiendo un tipo de responsabilidad objetiva. Esta propuesta no deja de ser interesante, pero dudamos que el legislador nacional así la haya asumido. En efecto, la tesis predominante en materia de responsabilidad descansa en la teoría de la culpa y no en la objetiva tal como lo dispone el artículo 1969 del Código Civil; en consecuencia, mal podría considerarse que para determinar la responsabilidad del demandante no se necesite acreditar su eventual culpabilidad, hecho que evidentemente, tal como están redactadas las normas actuales, tendría que efectuarse en un proceso judicial distinto al amparo y que carece de particularidad alguna.

En resumidas cuentas, podemos afirmar que la inclusión de la expresión "cuenta, costo y riesgo" en el proceso no ha importado ningún avance significativo en la regulación de la responsabilidad proveniente de la suspensión.

\section{e) El procedimiento para disponer la suspensión del acto}

El trámite procesal que debe seguirse para suspender el acto

(56) CHIOVENDA, Guiseppe. Instituciones de Derecho Procesal Civil. 2 da. Ed. Madrid: Editorial Revista de Derecho Privado, 1948, Vol. I, p. 282. 
reclamado ha generado fundadas criticas en distintos sectores, pues tales modificaciones llevadas a la realidad permiten desvirtuar el valor, eficacia, y fundamento de toda medida cautelar.

En primer lugar, se ha establecido que el incidente de suspensión debe seguirse en cuerda separada y con traslado a la parte emplazada por el término de un día. Ello, no sólo desvirtúa la naturaleza "inaudita pars" característica de las medidas cautelares, sino que además se fundamenta erróneamente en la necesidad de salvaguardar el derecho de defensa del demandado. A nuestro juicio, semejante posición no resulta conveniente pues el plazo establecido, que la práctica cotidiana se ha encargado de extender, facilita la irreparable ejecución del acto lesivo convirtiendo a la suspensión en un instrumento ineficaz. Así, en el clásico ejemplo de la resolución de alcaldía que en forma manifiestamente arbitraria dispone la demolición inmediata del inmueble en que domicilia el demandante, de correrse traslado a la otra parte, debido a la demora que ello implica, la resolución se ejecutaría y demolería dicho inmueble, con lo cual la medida cautelar habría perdido todo sentido. Más aún, sostener que la norma salvaguarda el derecho de defensa del emplazado resulta harto discutible pues el carácter "inaudita pars" (sin audiencia a la otra parte) no constituye ninguna arbitrariedad en detrimento de un derecho fundamental sino tan sólo una lógica consecuencia de la necesidad de mantener el valor eficacia que se vería afectado si se cumpliera con dicho trámite. En tal supuesto se estaría en presencia de una restricción razonable y temporal al principio de la bilateralidad de la audiencia (57).

(57) Al respecto Jorge Peyrano ha sostenido que "en varias hipótesis, aparentemente, no juega el principio de bilateralidad de la audiencia. Así, v.g., (. . .), sucede con el despacho de medidas cautelares (. . .). Preciso es aclarar que los casos que hemos propuesto como ejemplo no son excepciones al contradictorio, sino meras restricciones temporales a su vigencia. Ello porque (. . .) la bilateralidad de la audiencia reaparece pasada la oportunidad en que resultaba contraproducente su imperio". En $E l$ proceso civil. Principios y fundamentos. Buenos Aires: Astrea, 1978, pp. 154-155. 
En segundo lugar, la norma ha llegado al extremo de disponer que la resolución que otorga la suspensión "será recurrida en doble efecto ante la instancia superior". Es decir, concede la alzada no sólo con efecto devolutivo sino además con efecto suspensivo. Con ello se termina de facilitar el desfallecimiento de la materia de amparo, que contradictoriamente a través de la suspensión buscaba mantenerse con vida. De tal modo, en el hipotético caso que la autoridad policial sin contar con mandato judicial notifique a una persona que en fecha próxima y determinada ingresara a su morada para realizar un registro, amenazando su derecho a la inviolabilidad de domicilio; si se concediese la suspensión, bastará con apelar de ella para que la medida no se ejecute hasta que el recurso sea resuelto por el superior. De modo tal que en el caso en mención la medida cautelar no podría cumplir con su objetivo, es decir, impedir la consumación de la amenaza evitando la irreparabilidad del perjuicio, pues la urgencia que requiere su dictado y ejecución no se condice con la demora real que implica la revisión ante el Tribunal Superior. De esta manera, el legislador nacional, se ha afiliado a lo dispuesto por la Ley de Amparo Argentina (artículo 15 de la Ley No. 16986) que concede la apelación en "ambos efectos" desconociendo que ella ha sido severamente criticada por la generalidad de la doctrina platense (58), la cual la ha calificado incluso de inconstitucional (59), casualmente por impedir la inmediata ejecución de la medida cautelar decretada.

Sin lugar a dudas, la actual regulación del trámite para conceder la suspensión del acto no responde a su especial naturaleza

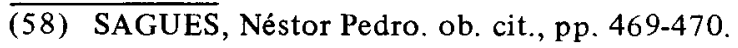

(59) DE LAZZARI, Eduardo Néstor. ob. cit., T. II, p. 267. El citado autor entiende "que la solución es inconstitucional y así podrán declararlo los jueces, en la medida en que la protección cautelar inaudita parte se vincula con la adecuada prestación del servicio de la justicia y con el resguardo pleno de los derechos de defensa y propiedad. La inviolabilidad de estos últimos no aparece suficientemente garantizada si no se estatuye un mecanismo que evite su frustración durante el lapso que insume el proceso de conocimiento". 
cautelar (60), por lo que en este aspecto la norma requiere una urgente modificación. En nuestra opinión, los términos de la reforma deberían encaminarse a regular un vehículo procesal expeditivo en el cual la regla general sea conceder la suspensión sin audiencia a la otra parte y siempre que "prima facie" estén presentes los presupuestos propios de toda medida cautelar. La excepción sería el traslado al emplazado cuando dichos presupuestos a criterio del juez no aparezcan del todo diáfanos, a fin de que el informe de la otra parte aclare tal situación. Además, pensamós que la reforma propuesta debería conceder la apelación tan sólo en efecto devolutivo -es decir sin suspender la ejecución de la resolución concedida-, y en la medida que el demandado previamente de cumplimiento a la orden de suspensión decretada.

\section{f) Algunos problemas que ha planteado la suspensión en el amparo}

En nuestro país el procesalismo científico no ha tenido mayor desarrollo. La vigencia de un Código de Procedimientos Civiles de 1912, cuya base teórica hunde sus raíces en la normatividad española del siglo pasado (1881), es un claro ejemplo de ello. Esta situación ha generado que las instituciones procesales $-y$ más aún su funcionamiento- no respondan idóneamente a las expectativas actuales. Ello ha venido sucediendo con la medida cautelar que salvo contadas excepciones - v.g. el embargo- no ha contado con regulación algu na (61). Sólo en los últimos años, tales medidas han

(60) Así por ejemplo, Rabel Vásquez de Velasco $P$., ha señalado que el actual procedimiento para conceder una suspensión, con traslado y apelación en ambos efectos, en la práctica judicial dura un mínimo de 33 días. Cfr. Las matemáticas de la mora del amparo, El Dominical, E1 Comercio, 24-09-89, p. 12.

(61) MONROY GALVEZ, Juan. Temás de proceso Civil, Lima: Studium, 1985 , p. 31 . A nivel jurisprudencial, como extraña excepción, el $12^{\circ}$ Juzgado Civil de Lima, Dr. J. Rodríguez Ayma, en el juicio ordinario seguido por Empresa de Transporte Aéreo del Perú S.A. AEROPERU con el Tribunal del Servicio Civil sobre impugnación de resolución administrativa, basándose equivocadamente en el art. II del Título Preliminat del Código Civil ("La Ley no ampara el abuso del Derecho. El intere- 
despertado un singular interés (62), que ha permitido la inclusión en el anteproyecto del Código de Procedimientos Civiles de todo un libro dedicado a su regulación (63). Sin duda, en ello ha influido el enorme auge obtenido por el empleo de la suspensión del acto reclamado en el proceso de amparo.

Esta falta de tradición en materia cautelar, explica en parte su deficiente regulación por la Ley No. 25011 , situación que recrudece debido a la imposibilidad de aplicar supletoriamente las normas

sado puede exigir la adopción de las medidas necesarias para evitar o suprimir el abuso y, en su caso, la indemnización que corresponda") dispuso la suspensión de los efectos de la resolución 0342-89-T SC del 22.06.89 hasta que se dicte sentencia definitiva en dicho proceso.

(62) A nuestro juicio, en el Perú el primer trabajo serio sobre la medida cautelar ha sido elaborado por MONROY GALVEZ, Juan, titulado: Introducción al estudio de la medida cautelar, ob. cit., pp. 11-86. Posteriormente, con el indudable auge de la suspensión en el amparo, se publicaron los siguientes ensayos: EGUIGUREN PRAELI, Francisco, La L.ey No. 25011 de reforma a la acción de amparo: razones para una discrepancia, pp. 87-105; MONROY GALVEZ, Juan, La medicla cautclar en el proceso de amparo, pp. 107-119. GARCIA BELAUNDE, Domingo. Las vueltas del amparo, pp. 121-127, QUIROGA LEON, Anibal. 1:7 Amparo y su modificación: la Ley No. 25011, pp. 129-140. Los citados trabajos fueron publicados en Lecturas sobre T'mus Constitucionales. No. 3, Lima: CAJ, 1989. Un último artículo en el que se aborda la problemática de la suspensión fue elaborado por ABAD Y., Samuel B., y SAN MARTIN C., César. La medida cautelar en el amparo: Ley 2.5011. Derecho y Sociedad, Revista de Derecho Pliblico, Año I, No. 1, octubre 1989, pp. 41-44. No obstante los esfuerzos realizados, aún en algunas esferas se sigue denominando a las medidas cautelares como "medidas precautelatorias o precautelativas", calificación que no sólo es técnicamente incorrecta (en realidad se trata de medidas cautelares o precautorias) sino más aún resulta evidentemente redundante.

(63) El referido anteproyecto fue elaborado por la Comisión Especial, constituida por R.M. No. 123-87-JUS, y presidida por C'́sar A. Mansilla Novella. Los primeros $\$ 2$ artículos aprobados por la Comisión en los que se desarrolla el Titulo Preliminar y la parte del Libro I, fueron publicados en separata especial de "El Peruano" el 05.02.1990. En dicha publicación se incluye el indice general del Anteproyecto de Código, cuyc, libro III está dedicado a regular los "Procesos Cautelares". 
procesales civiles - tal como sucede en Argentina- pues nuestro Código carece de una normatividad sistemática y coherente que permita suplir los vacíos existentes.

Ante tamaña situación, no debe llamar la atención la falta de respuesta legislativa a una serie de interrogantes que la experiencia de la suspensión en el amparo planteó abiertamente. Señalemos tan solo algunos ejemplos:

- La improcedencia de una medida cautelar. Hemos visto que ella resulta improcedente cuando no reune los presupuestos indispensables para su despacho. Sin embargo, la experiencia judicial ha mostrado determinados aspectos opinables que requieren de alguna precisión.

Así, a nuestro juicio no resulta viable la suspensión cuando existe con anterioridad un proceso de amparo seguido entre las mismas partes y por el mismo objeto, pues como hemos indicado si la demanda resulta manifiestamente improcedente por existir un proceso de amparo pendiente, la medida cautelar como lógica consecuencia también lo será; máxime si en el proceso anterior pudo evidentemente solicitarse la suspensión que se pretende. Esta causal de improcedencia del amparo no siempre ha sido entendida por nuestros tribunales, desconociendo por ejemplo la experiencia mexicana que rechaza al amparo interpuesto "contra leyes o actos que sean materia de otro juicio de amparo que se encuentra pendiente de resolución, ya sea en primera o única instancia, o en revisión, promovido por el mismo quejoso, contra las mismas autoridades y por el propio acto reclamado, aunque las violaciones constitucionales sean diversas" (art. 73, III, Ley de Amparo Mexicana).

Igualmente ha existido enorme discusión en torno a la posibilidad de dictar medidas cautelares contra resoluciones judiciales. Sobre el particular, un primer aspecto opinable es el relativo a determinar quién debe conceder la suspensión: el juez de Primera Instancia que actúa como Juez de trámite o la Corte Superior que dicta sentencia. En tal supuesto cabe destacar que la Corte Suprema en los autos "Miguel Valdivia Mares c/. Pri- 
mer Juzgado Civil de Tacna s/ acción de amparo" (El Peruano, -Ejecutorias Supremas- 03.09.84, pp. 2382-2363) sostuvo que el juez comisionado por la Corte Superior a que se refiere el artículo 29 de la Ley No. 23506, no cuenta con la atribución de disponer la suspensión del acto reclamado, pues de ella sólo puede hacer uso el juzgado cuando conoce originariamente en primera instancia. Un segundo aspecto opinable lo constituye el de determinar en que supuestos puede concederse la suspensión contra una resolución judicial. Sin duda en este punto ha existido una gran controversia propiciada por el frecuente pedido injustificado de medidas cautelares, lo cual ha motivado que por ejemplo en materia laboral se dicten normas expresas que dispongan que "En los casos en que se interponga la acción de amparo contra las resoluciones expedidas por el Fuero de Trabajo y Comunidades Laborales no será de aplicación lo dispuesto en el artículo 31 de la Ley No. 23506" (Décimo Segunda Disposición Transitoria, Dec. Leg. No. 384 de 29 de agosto de 1986). Sin embargo, lo dispuesto por la norma no resuelve plenamente el problema central, consistente en determinar en que casos debe habilitarse la suspensión en un proceso de amparo enderezado contra resolución judicial. En este aspecto, debemos tomar en consideración que una interpretación razonable de lo dispuesto por la Constitución y ciertamente de los artículos 5 y 6 Inc. 2 de la Ley No. 23506 puede conducirnos a sostener que el amparo frente a actos jurisdiccionales sólo es viable cuando dicho acto configure un atentado manifiesto al debido proceso legal (64). En tal situación, y no en otra, deberá habilitarse el amparo, ¿pero también la medida cautelar?. En nuestra opinión la respuesta debe ser afirmativa siempre que se cumpla con reunir los presupuestos propios de toda medida cautelar. Así por ejemplo, si en un proceso de aviso de despedida se dispone el lanzamiento de una persona a la cual no se le permitió ejercitar su derecho de defensa, ella para evitar el desalojo correspondiente podrá

(64) ABAD Y., Samuel B. ¿Procede el amparo contra resoluciones judiciales?. En: Lecturas sobre Temas Constitucionales No. 2, Lima: CAJ, 1988, pp. 35-71. 
obtener una medida cautelar para suspender tal acto lesivo. Empero no podemos dejar de reconocer lo delicado de esta situación, y la necesidad que la judicatura en casos como éste extreme la prudencia al momento de conceder una medida cautelar.

También ha generado importante discusión la posibilidad de otorgar la suspensión en un amparo interpuesto contra una norma de carácter general. En primer lugar debemos tomar en cuenta que el legislador no previó la hipótesis de un amparo frente a normas generales, sólo lo consintió frente a actos. Ello explica que la Exposición de Motivos del Anteproyecto de Ley de Habeas Corpus y Amparo elaborado por una Comisión presidida por el profesor Domingo García Belaunde indicara "que el Amparo y el Habeas Corpus no proceden contra normas, sino contra actos (acción u omisión)". Sin embargo, nuevamente la realidad ha desbordado lo dispuesto por la norma $y$ ha consentido en algunos casos la viabilidad del amparo enderezado directamente contra normas. En tales supuestos, no previstos por la ley, ¿debe o no concederse la suspensión? En principio debemos destacar que cuando el constituyente incorporó al amparo lo hizo sin establecer limitación expresa (contra cualquier autoridad, funcionario o persona), y cuando reguló la acción de inconstitucionalidad y la acción popular lo hizo en el primer caso prácticamente impidiendo la legitimación del particular afectado (deberán ser 50,000 ciudadanos los que la interpongan) y en ambos supuestos sin otorgarle a las sentencias correspondientes efectos retroactivos. Ello explica en parte el empleo del amparo frente a normas, que en nuestra opinión una interpretación amplia de la Constitución no podría rechazar. Obviamente, siempre que se trate de normas autoaplicativas (de aplicación inmediata) y no si se trata de normas heteroaplicativas (que requieren para su aplicación de un acto posterior) (65). Así por ejemplo, si entrara en

(65) Sobre el particular Arturo Gonzales Cosio, sostiene que "basta con que las leyes establezcan o contengan en sí mismas, un principio de ejecución, para que se les considere como Autoaplicativas y pueda ejercitar- 
vigencia una ley autoaplicativa que dispusiera el despido inmediato de todos los trabajadores sujetos al régimen de la actividad privada que tuvieran setenta o más años de edad, cualquier sindicato o los propios trabajadores afectados podrían interponer la demanda respectiva y solicitar la suspensión del acto reclamado a fin de paralizar el despido ordenado. En cambio, si se tratase de una ley heteroaplicativa que concediese al empleador cuando lo juzgue necesario la facultad de disponer el despido de las personas que cuentan con la indicada edad, el amparo no podría ser utilizado directamente contra dicha ley, pues se requeriría el acto de aplicación del empleador que disponga el despido del agraviado. En tal caso, por cierto, no podría concederse una medida cautelar. En resumidas cuentas si se tratase de una norma autoaplicativa y se reuniesen todos los demás presupuestos exigidos, podría otorgarse una medida cautelar. No obstante, en estos casos el juez debe ser particularmente riguroso para no trastocar el Estado de Derecho impidiendo la actuación legislativa y recordando como lo entendió la Corte Suprema Argentina en los autos "Francisco Orquin c/ Gobierno Nacional" que la medida cautelar "debe interpretarse restrictivamente cuando se la plantea respecto de la aplicación de las leyes, en cuanto juega a favor de éstas la presunción de validez de los actos de los poderes públicos" (66).

Durante el proceso de elaboración de la Ley No. 25011 (art. 31 ), uno de los proyectos formulados estableció expresamente determinados supuestos en los cuales resultaba improcedente conceder la suspensión. Así por ejemplo, no resultaba viable contra aquellos actos que protegieran la salud pública, aquellos que suprimieran los juegos de azar, aquellos encaminados a la investigación de un delito, o los que velaran por la moral pública. Dicha propuesta evidenciaba una clara influencia me-

se contra ellas la acción de amparo (. . .), porque hay leyes que por su sola expedición no causan perjuicio ni lesionan intereses de particulares. sino cuando son propiamente aplicadas, a las cuales se les denomina Heteroaplicativas". ob. cit., p. 66.

(66) Revista La Ley, Buenos Aires, Tomo 1984-A, p. 646. 
xicana, pues conforme lo dispone el artículo 124 II de su Ley de Amparo, la suspensión puede decretarse cuando de ella "no se siga perjuicio al interés social, ni se contravengan disposiciones de orden público. Se considerará, entre otros casos, que sí se siguen esos perjuicios o se realizan esas contravenciones, cuando, de concederse la suspensión: se continúe dl funcionamiento de centros de vicio, de lenocinios, la producción y el comercio de drogas enervantes; se permita la consumación o continuación de delitos o de sus efectos, o el alza de precios con relación a artículos de primera necesidad o bien de consumo necesario; se impida la ejecución de medidas para combatir epidemias de carácter grave, el peligro de invasión de enfermedades exóticas en el país, o la campaña contra el alcoholismo y la venta de substancias que envenenen al individuo o degeneren la raza; o se permita el incumplimiento de las órdenes militares".

El planteamiento previsto por la norma mexicana no constituye un temperamento aislado, pues la Ley Orgánica del Tribunal Constitucional Español (1979) al regular la suspensión en el amparo, dispone que ella podrá ser denegada cuando de no hacerlo se pudiera perturbar gravemente los intereses generales (art. 56).

Por cierto, la aplicación de tal supuesto exige una especial madurez de criterio del juzgador que permita equilibrar la magnitud del perjuicio que pueda sufrir el demandante de ejecutarse el acto lesivo, con el agravio susceptible de afectar los fines de interés colectivo buscados por el acto reclamado (67). Ello es explicable dado que el amparo, tal como lo señala Ignacio Burgoa, busca armonizar el interés particular del individuo con el in terés social, pues en dicho equilibrio se denota la búsqueda de mantener un régimen de derecho (68). En efecto, aparte de los casos expresamente mencionados por liu

(67) BURGOA, Ignacio. ob. cit., p. 737.

(68) Ibid., p. 744. 
ley mexicana, jurisprudencialmente ha quedado establecido que tampoco será viable la suspensión contra la aplicación de las leyes expropiatorias, contra la fijación del salario mínimo o contra aquellos actos que importen medidas de salubridad pública, etc. (69).

Ahora bien, en el caso peruano un requisito semejante al exigido por la ley mexicana carece totalmente de tratamiento legislativo y tampoco ha contado con un desarrollo jurisprudencial consistente. Unicamente ha destacado como notable excepción la resolución expedida por la Tercera Sala Civil de la Corte Superior de Lima (30.09.87) en el amparo seguido por "Teófilo Huertas Vega y otros con el Supremo Gobierno" donde se sostuvo que para conceder la suspensión entre otros aspectos, debía exigirse "que con ella no se ocasione perjuicio al interés general ni se contravengan disposiciones de orden público".

A nuestro juicio, la carencia de una norma como la mexicana podría ser suplida por un criterio jurisprudencial creador - prueba de ello es el fallo que como solitario ejemplo hemos citado- que determine cuando no debe concederse la suspensión pues de hacerlo se estaría atentando contra el interés social o disposiciones de orden público. Sin embargo debemos reconocer que la tendencia jurisprudencial predominante no viene exigiendo el cumplimiento de tal requisito, el cual en nuestro criterio debería ser pretoriamente observado.

- La inexistencia de prejuzgamiento. El dictado de una medida cautelar puede generar algunas discrepancias en relación a la. necesaria imparcialidad del juzgador al momento de dictar sentencia. En efecto, algu nos se han preguntado iel hecho que el juez haya otorgado o rechazado la suspensión solicitada le impide resolver el proceso principal por haber prejuzgado? ${ }_{¿} \mathrm{O}$ cuando la Corte conoció de la medida apelada ya no deberá

(69) Ibid., p. 746. 
dictar sentencia? ¿Acaso deberá aplicarse la causal de recusación prevista por el artículo 89 inciso 4 del Código de Procedimientos Civiles?

Ahora bien, si recordamos, siguiendo a Santiago Sentís Melendo, que el prejuzgamiento debe "referirse al mismo hecho contemplado en toda su amplitud y en la totalidad del material probatorio, tanto si (. . .) se produce en el mismo proceso como si se produce un proceso distinto" (70), podremos concluir que en rigor el juez o la Corte en los casos mencionados no llega a prejuzgar. $Y$ no lo hace porque la visión del juzgador al momento de evaluar el pedido cautelar no es plena, sino restringida al examen de los presupuestos propios de toda medida cautelar y limitada a una investigación probatoria mínima, distinta a la exigida al momento de dictar sentencia. Por lo demás, así lo considera tanto el propio autor citado como el procesalista Eduardo De Lazzari (71), posición que en Argentina cuenta con el respaldo de la tendencia jurisprudencial predominante. Sin embargo, conviene precisar -como necesario límite-, que si el juez lejos de avocarse a examinar los elementos probatorios indispensables para otorgar la suspensión solicitada, se extralimita groseramente y evalúa los aspectos referidos al fondo del asunto, podrá decirse que ha prejuzgado (72).

- La modificación de una medida cautelar. Como se recordará, una de las notas características de las medidas cautelares es la llamada variabilidad. Ello significa que "pueden estar sujetàs, aún antes de que se dicte la providencia principal, a modificaciones correspondientes a una posterior variación de las circunstancias concretas, todas las veces que el juez, a través de una nueva providencia considere que la medida cautelar ini-

(70) SENTIS MELENDO, Santiago. Enciclopedia Juridica Omeba, Buenos Aires: Edit. Bibliográfica Argentina, 1964, Tomo XXII, voz: Prejuzgamiento, p. 848 .

(71) DE LAZZARI, Eduardo Néstor. ob. cit., T. I, p. 31.

(72) SENTIS MELENDO, Santiago. ob. cit., pp. 838-839. 
cialmente ordenada no está ya adecuada a la nueva situación de hecho creada durante ese tiempo" (73). Esta característica no es ajena al juicio de amparo mexicano pues incluso en él se faculta al juez, mientras no haya sido dictada sentencia definitiva, a modificar o revocar la resolución que haya concedido o negado la suspensión, en la medida que ocurra un hecho superviniente que le sirva de fundamento (Ley de Amparo, art. 140).

Frente al panorama descrito, resulta fácil apreciar la precariedad con que cuenta el artículo 31 de nuestra Ley, pues no le brinda la más mínima atención al carácter variable de la suspensión. No obstante, debido a que hemos considerado a dicha institución como una verdadera medida cautelar es que no podemos negarle - pese al vacío legisla tivo existente- su naturaleza variable, siendo por ello necesario acudir a la doctrina que la informa.

En efecto, la teoría exige para la modificación o revocación correspondiente, no sólo que esté en curso el proceso de amparo, es decir que aún no haya culminado, sino fundamentalmente que varíen las circunstancias existentes o ocurran hechos supervinientes que inicialmente no hayan estado presentes.

Así las cosas, si luego de haber sido rechazada la suspensión solicitada por no haber reunido los presupuestos establecidos, se presentan hechos o circunstancias nuevas que denotan la existencia de los requisitos inicialmente ausentes, podrá el juez conceder la suspensión. De tal modo, en el caso hipotético que se niegue la medida cautelar solicitada por no ser aún irreparable el daño alegado, si debido a un hecho posterior se hace necesario dadas las circunstancias existentes suspender el acto lesivo, el juez que inicialmente rechazó el pedido deberá acceder a lo solicitado modificando su anterior resolución. No hacerlo, y en consecuencia negar el carácter variable de la

(73) CALAMANDREI, Piero. ob. cit., p. 89. 
medida cautelar, atentaría contra el valor eficacia, fundamento de dicha institución, impidiendo que en su momento se pueda ejecutar la sentencia obtenida, y haciendo desfallecer la materia amparo.

Ahora bien, dos aspectos finales merecen especial atención. En primer lugar, determinar si luego de haber sido apelada la resolución cautelar y antes de ser resuelta, puede el juez modificarla o revocarla. Sobre el particular es preciso distinguir los motivos de la apelación, de las razones que acreditan la variación de una medida cautelar. Como lo recuerda Couto, la Corte cuando conoce de la apelación lo hace evaluando las consideraciones legales que sirvieron de fundamento a la resolución cautelar, sin examinar las circunstancias posteriores o los motivos sobrevinientes que debieran ameritar su variación; en consecuencia el juez al alterar la resolución cautelar no afecta la materia que viene conociendo la Corte Superior, es decir, no invade su esfera de competencia (74).

En segundo lugar, si la resolución apelada ha sido confirmada por la Corte Superior, ¿podría el juez variar la suspensión otorgada? Si seguimos el razonamiento anterior, podemos distinguir el motivo de la apelación - la ausencia o el error en el momento de dictarse la suspensión de los presupuestos indispensables para su despacho-, de las razones posteriores -hechos o circunstancias sobrevinientes- que fundamentan la variación. Ahora bien, acogiendo dicha distinción el juez podrá revocar o modificar la suspensión siempre que ella se base en la presencia de un elemento posterior, ausente en el momento en que se decretó la medida cautelar. Sólo en ese supuesto, no existiría obstáculo alguno para que el juez haga uso de la facultad de variar la suspensión otorgada (75). En consecuencia, si el juez dispusiera la modificación de una resolución por los mismos fundamentos que ameritaron la confir-

(74) COUTO, Ricardo. ob. cit., p. 202

(75) Ibid., p. 202. 
matoria de la Corte Superior, actuaría invadiendo esferas que no son de su competencia.

La ejecución de la medida cautelar. Uno de los graves problemas con los que se ha enfrentado la suspensión en nuestro país, ha sido la falta de una adecuada normatividad que regule la forma en que debe ser acatada y el consiguiente apercibimiento que facilite su ejecución ante la desobediencia del demandado. Sin duda en este aspecto nuestra ley de amparo ha dejado un serio vacío que no sólo atenta contra la eficacia de la medida cautelar, sino que llega a remover las bases mismas del Poder Judicial, pues ¿acaso es concebible un poder que administra justicia y no pueda ejecutar la decisión dictada con la urgencia e idoneidad requerida?

En efecto, en la actualidad luego del "cúmplase" correspondiente el juez de amparo para poder ejecutar la suspensión decretada, se encuentra limitado a oficios a la Corte a fin de que el emplazado acate inmediatamente lo resuelto, bajo apercibimiento de ser denunciado penalmente por la inobservancia del mandato judicial. Este apercibimiento, restringido a una posterior sanción penal luego del proceso correspondiente, no satisface las mínimas expectativas que el justiciable requiere. Así las cosas, si ante el ejemplo que hemos venido utilizando de una resolución de alcaldía que dispone arbitrariamente la demolición de un inmueble, se concediera la suspensión y no fuera cumplida, ¿acaso la posterior sanción penal sería suficiente para salvaguardar las pretensiones del quejoso? Evidentemente que no, pues durante la secuela del proceso penal, con la intervención inicial del Ministerio Público, el inmueble por la demora correspondiente sería demolido y el demandante se encontraria ante la difícil realidad de contar con un mandato cautelar que no pudo lograr su cometido, es decir que fue incapaz de mantener viva la materia de amparo. Con ello no sólo se vería afectado el justiciable, sino en conjunto se desprestigiaría aún más la criticada función jurisdiccional.

Este problemático vacío en la legislación nacional merece ser urgentemente solucionado, por ello en una propuesta de reforma debería pensarse por ejemplo en una institución de origen 
angloamericano conocida como desacato disciplinario ("contempt of court") cuyo cometido facilita la obediencia de los mandatos judiciales, permitiendo al juez ante el incumplimiento del emplazado disponer su inmediata detención o arresto, o de ser el caso, imponerle una multa que podría ir aumentando progresivamente (astreintes). Con ello se lograría, ante el temor de un severo apercibimiento, que el demandado cumpla con la resolución cautelar independientemente de la posterior sanción penal que sin duda debe seguir existiendo, pues el desacato disciplinario se limita a constituir un medio de coacción personal para obtener la ejecución de un mandato cautelar y carece de efectos punitivos (76). Asimismo, el derecho mexicano ha previsto otros importantes mecanismos destinados a lograr el cumplimiento de la suspensión. Así por ejemplo se dispone que si dentro de las veinticuatro horas siguientes a la notificación al demandado, la resolución no es cumplida, se requerirá al superior jerárquico de la autoridad emplazada, para que lo obligue a cumplir con tal resolución, y si careciera de una autoridad superior se requerirá directamente al demandado (Ley de Amparo, art. 105).

Al margen de ello puede el juez comisionar al Secretario de Juzgado para hacer cumplir su mandato o constituirse él mismo para ejecutarlo, pudiendo solicitar el auxilio de la fuerza pública (Ley de Amparo, art. 111) (77).

No obstante la presencia en el panorama procesal de tales medidas, el legislador nacional no las tomó en consideración y elaboró una norma (el Art. 31) que en la práctica ante su incumplimiento no permite su inmediata ejecución, generando la insatisfacción de los justiciables. Por ello, en este aspecto se requiere una urgente reforma de nuestra legislación que acuda a la experiencia comparada y que no olvide como lo expresa

(76) PEYRANO, Jorge. Medida cautelar innovativa, Buenos Aires: Depalma, 1981, p. 117.

(77) BURGOA, Ignacio. ob. cit., p. 808. 
Peyrano "que el juez debe echar mano, si es que desea prestar jurisdicción de modo eficaz, a los apercibimientos judiciales para encausar o impulsar el trámite. Bienvenidos sean, entonces, los magistrados ingeniosos que saben dar en la tecla al formular el apercibimiento judicial más indicado en el caso. Con ello queda demostrado, una vez más, que la judicatura moderna (aparte de prudente y sabia) debe también ser "imaginativa"' (78).

\section{A MODO DE REFLEXION FINAL}

A lo largo del presente trabajo hemos destacado la insuficiencia del artículo 31 de la Ley para regular la suspensión en el proceso de amparo, así como la falta de una teoría coherente que le diera sustento. Estos aspectos, aunados a la escasa creación jurisprudencial por parte de nuestros tribunales y al frecuente empleo indiscriminado de esta institución, han hecho que la medida cautelar en el amparo se encuentre atravesando una difícil situación.

Frente a este panorama, las críticas y propuestas de reforma planteadas en el presente documento no pueden ser concebidas si se olvidara que quien en definitiva otorgará la suspensión solicitada será el juzgador, y es ahí donde el criterio judicial, sereno y maduro adquiere especial importancia, pues corresponderá finalmente a la judicatura el otorgamiento de una medida de suspensión y, en consecuencia, en ella ha de recaer la grave responsabilidad de hacerlo con cautela e idoneidad. Es evidente entonces que las palabras empleadas por Carnelutti resultan plenamente aplicables, pues en definitiva el gran problema del proceso y concretamente de la medida cautelar depende mucho de encontrar al hombre digno de juzgar.

(78) PEYRANO, Jorge. ob. cit., p. 101. 